\title{
Oxygen isotope composition of a section of lower oceanic crust, ODP Hole 735B
}

\author{
Jeffrey C. Alt \\ Department of Geological Sciences, University of Michigan, 2534 C.C. Little Building, Ann Arbor, Michigan 48109- \\ 1005,USA (jalt@umich.edu)

\section{Wolfgang Bach} \\ Universität Bremen, Fachbereich 5 - Geowissenschaften, Postfach 3304 40, D-28334 Bremen, Germany \\ (wbach@uni-bremen.de)
}

[1] The oxygen and hydrogen isotope compositions of vein minerals and $\delta^{18} \mathrm{O}$ values of 64 whole rocks from the deeper kilometer of the $1.5 \mathrm{~km}$ lower crustal section of ODP Hole 735B in the SW Indian Ocean were analyzed in order to investigate seawater penetration into and reaction with the lower oceanic crust. Vein amphiboles have $\delta \mathrm{D}$ values of -35 to $-65 \%$, indicating formation from seawater fluids and hydrothermal fluids containing a component of low- $\delta$ D magmatic fluid. Crystal-plastic shear zones reacted with ${ }^{18} \mathrm{O}$-enriched fluids at high temperatures and have $\delta^{18} \mathrm{O}$ values of $6.0-7.0 \%$, indistinguishable from surrounding rocks. Reaction with seawater-dominated fluids over a range of temperatures $\left(\sim 350-700^{\circ} \mathrm{C}\right)$ led to local ${ }^{18} \mathrm{O}$-depleted rocks, but much of the section exhibits ${ }^{18} \mathrm{O}$ enrichment $\left(\delta^{18} \mathrm{O}\right.$ up to $7.6 \%$ ) as the result of static alteration of plagioclase over a range of temperatures $\left(<250\right.$ to $\left.\sim 600^{\circ} \mathrm{C}\right)$ and fluid compositions. Chloritic veins and associated alteration by ${ }^{18} \mathrm{O}$-enriched fluids occurred at temperatures of $150-250^{\circ} \mathrm{C}$, and late carbonates and Fe-oxyhydroxides formed from cold $\left(\sim 10^{\circ}\right)$ seawater associated with open fault-related fractures. Bulk rock $\delta^{18} \mathrm{O}$ values of the lower $1 \mathrm{~km}$ range from 3.7 to $10.2 \%$ o but are mostly 5.6-7.6\%o, and the section has a mean bulk $\delta^{18} \mathrm{O}$ of $6.5 \pm 1.0 \%$. In contrast, rocks from the shallower $500 \mathrm{~m}$ exhibit net ${ }^{18} \mathrm{O}$ depletion $(5.1 \pm 1.0 \%)$ reflecting high-temperature deformation and seawater hydrothermal alteration (Stakes, 1991). The weighted average $\delta^{18} \mathrm{O}$ for the entire gabbro section of Hole $735 \mathrm{~B}$ is $6.0 \%$, exhibiting little or no change compared to unaltered crust. Although tectonism at slow spreading rates may allow exposure of lower crust to greater amounts of low-temperature alteration and ${ }^{18} \mathrm{O}$ enrichment, there is no evidence for a consistent difference in the bulk $\delta^{18} \mathrm{O}$ of the plutonic sections of oceanic crust formed at fast versus slow spreading rates.

Components: 11,535 words, 7 figures, 3 tables.

Keywords: isotope geochemistry; hydrothermal systems; mid-ocean ridges; gabbro.

Index Terms: 1041 Geochemistry: Stable isotope geochemistry (0454, 4870); 3035 Marine Geology and Geophysics: Midocean ridge processes; 3616 Mineralogy and Petrology: Hydrothermal systems (0450, 1034, 3017, 4832, 8135, 8424).

Received 7 June 2006; Revised 4 October 2006; Accepted 18 October 2006; Published 29 December 2006.

Alt, J. C., and W. Bach (2006), Oxygen isotope composition of a section of lower oceanic crust, ODP Hole 735B, Geochem. Geophys. Geosyst., 7, Q12008, doi:10.1029/2006GC001385. 


\section{Introduction}

[2] Because of the temperature-dependent fractionation of oxygen isotopes between minerals and water, low-temperature $\left(<200^{\circ} \mathrm{C}\right)$ alteration of oceanic crust by seawater leads to ${ }^{18} \mathrm{O}$ enrichment of the crust relative to unaltered basalt, whereas hydrothermal alteration $\left(>250^{\circ} \mathrm{C}\right)$ leads to ${ }^{18} \mathrm{O}$ depletions in the rocks [Muehlenbachs and Clayton, 1972, 1976]. It is the balance between these processes that helps buffer the $\delta^{18} \mathrm{O}$ of the oceans [Muehlenbachs and Clayton, 1976; Gregory, 1991; Muehlenbachs, 1998].

[3] The original model for the buffering of seawater composition by ocean crustal alteration is based on analyses of rocks dredged from the seafloor [Muehlenbachs and Clayton, 1976]. Since then many studies of rocks sampled by drilling and submersible have been carried out, providing a more detailed view of alteration of the oceanic crust [e.g., Alt, 1995]. The volcanic section of oceanic crust altered at low temperatures $\left(<150^{\circ} \mathrm{C}\right)$ has been sampled extensively and is consistently enriched in ${ }^{18} \mathrm{O}$ to varying degrees (summaries by Muehlenbachs [1980, 1998] and Alt [2003, 2004]). The lower, plutonic section of oceanic crust is more difficult to sample, however, and very few well-studied sections have been analyzed for oxygen isotopes (i.e., Hess Deep and Cayman Trough [Ito and Clayton, 1983; Agrinier et al., 1995; Fruh-Green et al., 1996; Lecuyer and Gruau, 1996; Gillis et al., 2001)]. These oceanic plutonic sections are generally depleted in ${ }^{18} \mathrm{O}$, as are plutonic sections in most ophiolites [Gregory and Taylor, 1981; Cocker et al., 1982; Elthon et al., 1984; Stakes and Taylor, 1992; Bickle and Teagle, 1992; Alt and Teagle, 2001]. The plutonic sections of some ophiolites, however, are enriched in ${ }^{18} \mathrm{O}$ [Agrinier et al., 1988; Harper et al., 1988; Barrett and Friedrichsen, 1989; Schiffman et al., 1991; Lecuyer and Fourcade, 1991]. Thus there is a need to better understand seawater penetration into the lower oceanic crust and the factors leading to ${ }^{18} \mathrm{O}$-enrichment or depletion of different sections of the lower crust, and how these relate to the variability and overall $\delta^{18} \mathrm{O}$ of the lower oceanic crust.

[4] A key factor for introduction of water into the lower ocean crust is deformation. At slow spreading centers normal faults penetrate the brittle-ductile transition resulting in plastic deformation and dynamic metamorphism at granulite to amphibolite facies conditions [Ito and Clayton,
1983; Mevel and Cannat, 1991; Stakes et al., 1991; Stakes, 1991]. Subsequent brittle deformation allows penetration of hydrothermal fluids into the lower crust at amphibolite to greenschist and lower grade conditions along fracture networks and faults [Cannat et al., 1991; Stakes et al., 1991; Mevel and Cannat, 1991]. Observations from Hess Deep and ODP Site 1256 in the eastern Pacific suggest that high-temperature plastic deformation and metamorphism are generally lacking in crust generated at fast and superfast spreading rates, and that hydrothermal fluids penetrate downward at amphibolite to greenschist and lower grade conditions along fracture networks [Manning et al., 2000; Gillis, 1995; Fruh-Green et al., 1996; Wilson et al., 2006]. Retrograde alteration is common in in situ uppermost gabbros at Site 1256 [Expedition 309 and 312 Scientists, 2006]; however, at Hess Deep this is related to propagation of the Galapagos rift and may not be representative of crust generated at fast spreading rates [Fruh-Green et al., 1996].

[5] The $1500 \mathrm{~m}$ gabbro section of ODP Hole 735B in the SW Indian Ocean is one of the longest intact sections of lower oceanic crust available, and the core, having $\sim 90 \%$ recovery, has been logged in detail [Dick et al., 2000]. The upper $500 \mathrm{~m}$ of gabbros cored on Ocean Drilling Program (ODP) Leg 118 are generally depleted in ${ }^{18} \mathrm{O}$ relative to fresh basalt, and this ${ }^{18} \mathrm{O}$-depletion diminishes with increasing depth, consistent with observed metamorphic and deformation effects in the rocks [Stakes, 1991; Stakes et al., 1991]. Only limited oxygen isotope data, however, exist for the lower $1 \mathrm{~km}$ cored on ODP Leg 176 [Bach et al., 2001a; Gao et al., 2006], and these studies focused on igneous phases and rocks affected by late lowtemperature alteration, so the majority of rock and alteration types have not been analyzed for oxygen isotope composition.

[6] This paper presents oxygen isotope analyses of whole rocks from the lower $1 \mathrm{~km}$ of Hole $735 \mathrm{~B}$ in order to investigate seawater penetration into and reaction with the lower oceanic crust. Secondary minerals in veins were also analyzed for oxygen and hydrogen isotope compositions in order to constrain the temperatures and compositions of fluids in the 735B gabbro section. Samples include rocks representative of the different igneous rock types, as well as rocks exhibiting varying degrees of recrystallization and different styles of alteration. Sampling across major zones of plastic and 


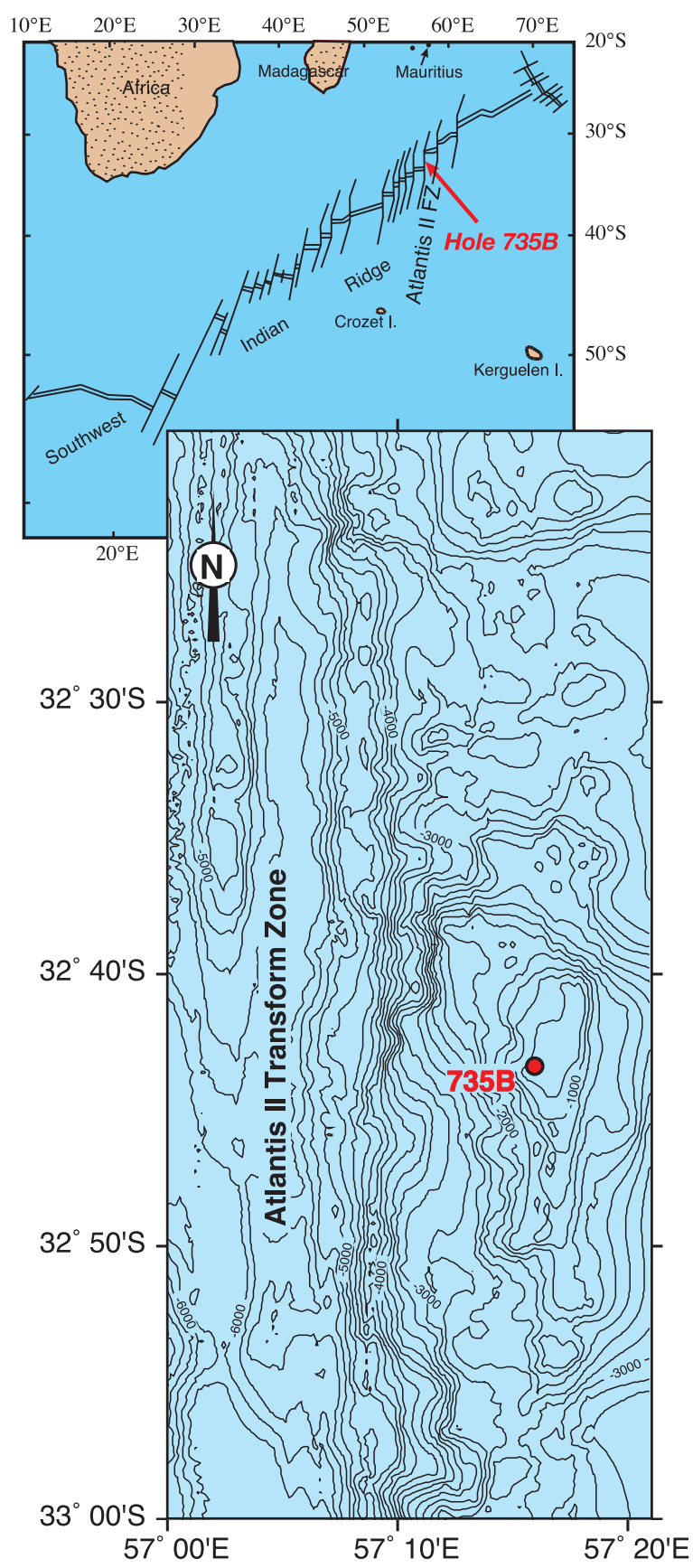

Figure 1. Location of Hole 735B east of the Atlantis II Fracture Zone along the SW Indian Ridge, $32^{\circ} \mathrm{S}, 58^{\circ} \mathrm{E}$. After Dick et al. [1991] and Bach et al. [2001a].

brittle deformation was included in order to evaluate these zones as pathways for fluid penetration into the lower oceanic crust. We compare oxygen isotope alteration effects in plutonic sections of crust formed at fast and slow spreading rates in order to assess any spreading rate dependence.

\section{Hole 735B}

[7] Hole 735B is located on Atlantis Bank, an uplifted block of $\sim 12$ Ma lower ocean crust near the Atlantis II fracture zone on the slow-spreading $\left(0.6-1.0 \mathrm{~cm} \mathrm{y}^{-1}\right) \mathrm{SW}$ Indian Ridge (Figure 1). The Atlantis Bank gabbros formed at the axis about $15 \mathrm{~km}$ from the active transform fault, and were unroofed by a major detachment fault [Dick et al., 1991, 2000]. Hole 735B was cored on two ODP legs: the upper $504 \mathrm{~m}$ was penetrated during Leg 118 in 1987 [Von Herzen et al., 1989], and a further $1004 \mathrm{~m}$ was cored on Leg 176 in 1997 [Dick et al., 2000], for a total lower crustal penetration of $1508 \mathrm{~m}$ with $87 \%$ recovery of gabbroic rocks. Fluid inclusions in the uppermost gabbros formed at hydrostatic pressures equivalent to $1.5-2 \mathrm{~km}$ below the seafloor [Vanko and Stakes, 1991], suggesting that the cored section is from the upper portion of the plutonic section of oceanic crust.

[8] The Hole 735B section is predominantly olivine gabbro, but rock types include gabbro, gabbronorite, oxide gabbro, disseminated oxide gabbro, oxide gabbronorite, and troctolite [Shipboard Scientific Party, 1999; Dick et al., 2000]. The plutonic section formed via a series of small magma bodies affected by syntectonic differentiation and migration of late iron rich melts into shear zones. The oxide-rich zones commonly exhibit crystal-plastic and brittle-ductile deformation. Present locally in the core are small amounts $(0.5 \%$ by volume $)$ of felsic veins that have dioritic to granitic compositions. These formed from late magmatic melts and fluids, but have a seawater hydrothermal overprint [Stakes, 1991; Dick et al., 2000; Bach et al., 2001b].

[9] The rocks preserve a record of high-temperature metamorphism, brittle failure, and hydrothermal alteration that began at near solidus temperatures and continued down to very low grade conditions [Stakes et al., 1991; Shipboard Scientific Party, 1999; Dick et al., 2000]. Crystal-plastic deformation occurred at up to granulite facies conditions (recrystallization of plagioclase and pyroxene at $800-$ $1000^{\circ} \mathrm{C}$ ). These effects are greatest in the upper $200 \mathrm{~m}$ and are present mainly in two broad zones at $500-700 \mathrm{~m}$ and $800-960 \mathrm{~m}$, but crystal-plastic shear zones are present at 945-964 m and $1325 \mathrm{~m}$ (Figure 2). Amphibole and less calcic secondary plagioclase formed in deformed rocks mainly in 

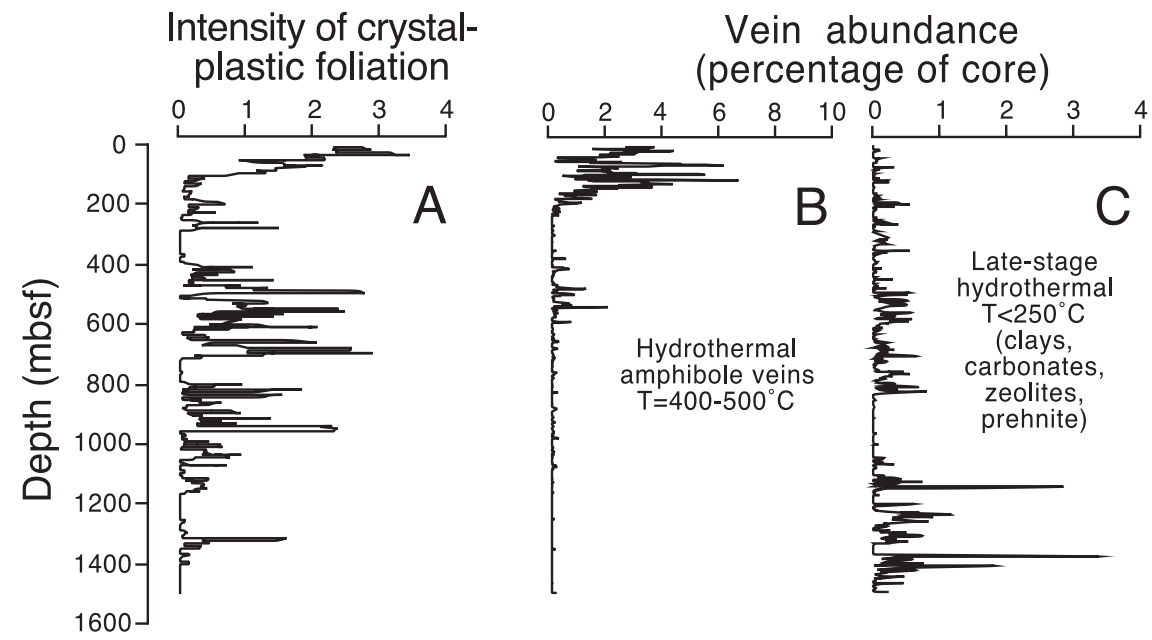

Figure 2. Variation of (a) intensity of ductile deformation, (b) abundances of amphibole veins, and (c) low-grade metamorphic veins in Hole 735B. Crystal plastic deformation plotted as $2 \mathrm{~m}$ running average; scale ranges from 0 (undeformed) to 5 (ultramylonite). Vein abundances are plotted as 5-m running average. See Shipboard Scientific Party [1999] for details. After Bach et al. [2001a].

the upper $600 \mathrm{~m}$ as temperatures decreased [Stakes et al., 1991; Cannat et al., 1991; Shipboard Scientific Party, 1999].

[10] During subsequent brittle deformation pyroxene and plagioclase along veins and microcracks were partly replaced by green amphibole and sodic plagioclase. In the host rocks static alteration varies from slight (e.g., cracks in olivine filled with talc + magnetite) to reaction coronas around mafic igneous minerals, characterized by talc, amphiboles, phlogopite, and chlorite [Vanko and Stakes, 1991; Stakes et al., 1991; Shipboard Scientific Party, 1999]. Clinopyroxene is variably replaced by amphiboles and trace chlorite, and plagioclase is variably replaced by amphibole. The abundance of amphibole veins decreases significantly below about $700 \mathrm{~m}$ (Figure 2), but brittle deformation (veining) and lower-temperature minerals are locally present, including prehnite, chlorite-smectite, smectite, iron oxyhydroxides, and calcite.

[11] Brittle faults occur at 490, 560 and 690700 mbsf, and several minor zones of cataclasis occur at 1076 and 1100-1120 mbsf. Lowtemperature alteration and oxidation are associated with the faults at 490 and $560 \mathrm{~m}$ [Alt and Bach, 2001; Bach et al., 2001a], but higher-temperature phases (amphibole, plagioclase) are also associated (especially at $\sim 700 \mathrm{~m}$ ).

[12] Secondary mineral veins comprise $\sim 1 \%$ of the core by volume (Figure 2). Vein types include amphibole, minor carbonate (mainly at 500-
$600 \mathrm{~m}$ ), phyllosilicates, common zeolite and prehnite, and rare quartz and epidote.

[13] Bach et al. [2001a] divided the Hole 735B core into different zones on the basis of lowtemperature alteration assemblages. Table 1 shows these zones, with additional data for the average amounts of recrystallization to high-temperature alteration minerals as determined by visual core descriptions [Shipboard Scientific Party, 1999]. Alteration is heterogeneous on the cm scale, however, so individual samples can vary greatly from the averages in Table 1 . The most intensely altered portion of the Leg 176 core is 500-600 mbsf, where amphibole and secondary plagioclase, as

Table 1. Alteration Zones in Hole $735 \mathrm{~B}^{\mathrm{a}}$

\begin{tabular}{ccccc}
\hline & & \multicolumn{3}{c}{$\begin{array}{c}\text { Average Percent } \\
\text { Alteration }\end{array}$} \\
\cline { 3 - 4 } $\begin{array}{c}\text { Alteration } \\
\text { Zone }\end{array}$ & $\begin{array}{c}\text { Depth Interval, } \\
\text { mbsf }\end{array}$ & High-T & Low-T & Type \\
\hline $1^{\prime}$ & $0-40$ & 45 & 3 & ox \\
$2^{\prime}$ & $40-500$ & 30 & 2 & nox \\
1 & $500-600$ & 10 & 8 & ox \\
2 & $600-835$ & 8 & 2 & nox \\
3 & $835-1050$ & 15 & $<1$ & nox \\
4 & $1050-1300$ & 3 & 4 & nox \\
5 & $1300-1475$ & 2 & 2 & nox \\
6 & $1475-1506$ & 2 & 2 & gs \\
\hline
\end{tabular}

${ }^{\mathrm{a}}$ Alteration zones from Bach et al. [2001a]. Notes: mbsf, meters below seafloor; Type is low-T alteration type; ox, oxidative; nox, nonoxidative; gs, greenschist. High-T refers to high-temperature metamorphism (granulite down to amphibolite and upper greenschist grades); Low-T refers to lower greenschist and lower grade(smectitic) alteration. Data from Bach et al. [2001a], Stakes et al. [1991], and Shipboard Scientific Party [1999]. 
Table 2. Bulk Rock Oxygen Isotope Data for Hole $735 \mathrm{~B}^{\mathrm{a}}$

\begin{tabular}{|c|c|c|c|c|c|c|c|c|c|}
\hline Core & $\mathrm{S}$ & Interval, cm & Depth, mbsf & $\%$ Alt & Rock Type & $\delta^{18} \mathrm{O}$ & CP Fabric & $\mathrm{Mg} \#$ & Shear/Fault \\
\hline 90R & 1 & $115-121$ & 508.9 & 1 & OG & 6.2 & 0 & 80.9 & \\
\hline $91 \mathrm{R}$ & 3 & $125-130$ & 521.2 & 8 & OG & 6.8 & 0 & 76.3 & \\
\hline $91 \mathrm{R}$ & 3 & $90-95$ & 520.9 & 30 & OG & 8.2 & 0 & 56.4 & breccia \\
\hline $93 R$ & 1 & $75-81$ & 532.9 & 6 & $\mathrm{DOxG}$ & 6.0 & 1 & 72.3 & \\
\hline $93 R$ & 1 & $86-91$ & 533.0 & 13 & DOxG & 5.7 & 1 & 69.4 & \\
\hline $97 \mathrm{R}$ & 1 & $125-130$ & 557.4 & 60 & DOxG & 3.9 & 2 & 62.5 & fault \\
\hline $102 \mathrm{R}$ & 1 & $17-23$ & 590.1 & 50 & OxG & 6.2 & 2 & 23.1 & \\
\hline $103 R$ & 1 & $72-80$ & 595.8 & 2 & $\mathrm{OxG}$ & 6.3 & 2 & 31.8 & \\
\hline $103 R$ & 2 & $120-125$ & 597.4 & 3 & G & 6.5 & 0 & 68.6 & \\
\hline $103 R$ & 2 & $139-142$ & 597.6 & 13 & $\mathrm{G}$ & 6.0 & 1 & 70.8 & \\
\hline $110 \mathrm{R}$ & 4 & $0-5$ & 637.1 & 20 & $\mathrm{FV}$ & 6.9 & 0 & 80.9 & \\
\hline $110 \mathrm{R}$ & 4 & $56-63$ & 637.6 & 2 & OG & 6.6 & 0 & 80.9 & \\
\hline $114 \mathrm{R}$ & 1 & $92-96$ & 653.5 & 12 & OxGN & 7.2 & 1 & 50.7 & \\
\hline $114 \mathrm{R}$ & 5 & $23-29$ & 659.5 & 80 & OxGN & 6.2 & 0 & 37.8 & \\
\hline $117 \mathrm{R}$ & 2 & $42-48$ & 683.5 & 55 & GN & 7.7 & 2 & 66.3 & \\
\hline $119 \mathrm{R}$ & 1 & $72-77$ & 701.4 & 70 & $\mathrm{G}$ & 6.6 & 4 & 63.7 & mylonite \\
\hline $120 \mathrm{R}$ & 4 & $62-67$ & 714.9 & 60 & $\mathrm{FV}$ & 4.6 & 0 & 55.2 & \\
\hline $120 \mathrm{R}$ & 6 & $34-41$ & 717.5 & 2 & OG & 6.6 & 0 & 72.3 & \\
\hline $124 \mathrm{R}$ & 1 & $32-38$ & 749.0 & 2 & OG & 7.0 & 0 & 74.0 & \\
\hline $128 \mathrm{R}$ & 2 & $133-137$ & 778.4 & 2 & OG & 6.7 & 0 & 74.5 & \\
\hline $130 \mathrm{R}$ & 4 & $121-127$ & 799.4 & 12 & OG & 6.9 & 0 & 63.8 & \\
\hline $132 \mathrm{R}$ & 1 & $70-78$ & 813.9 & 21 & $\mathrm{G}$ & 6.0 & 1 & 72.7 & \\
\hline $132 \mathrm{R}$ & 1 & $94-99$ & 814.2 & 8 & G & 5.9 & 0 & 72.5 & \\
\hline $132 \mathrm{R}$ & 8 & $103-109$ & 823.2 & 14 & OG & 6.6 & 0 & 71.3 & \\
\hline $132 \mathrm{R}$ & 8 & $112-118$ & 823.3 & 4 & OG & 6.0 & 0 & 69.2 & \\
\hline $134 \mathrm{R}$ & 2 & $105-110$ & 834.9 & 1 & OG & 6.8 & 0 & 75.4 & \\
\hline $135 \mathrm{R}$ & 1 & $97-103$ & 843.1 & 70 & DOxG & 6.6 & 3 & 66.2 & \\
\hline $135 \mathrm{R}$ & 3 & $98-99$ & 845.7 & 50 & FV & 6.2 & 0 & 48.9 & \\
\hline $139 \mathrm{R}$ & 4 & $68-74$ & 875.9 & 1 & OG & 6.8 & 1 & 75.0 & \\
\hline $142 R$ & 7 & $15-18$ & 901.2 & 1 & OG & 6.8 & 1 & 67.8 & \\
\hline $144 R$ & 5 & $0-9$ & 917.9 & 12 & DOxG & 6.7 & 1 & 56.6 & \\
\hline $145 R$ & 4 & $38-44$ & 926.4 & 1 & OG & 6.1 & 0 & 77.4 & \\
\hline $147 R$ & 6 & $45-54$ & 947.4 & 80 & $\mathrm{G}$ & 6.8 & 3 & 69.0 & shear \\
\hline $148 \mathrm{R}$ & 1 & $101-103$ & 951.9 & 1 & OG & 6.6 & 2 & 75.8 & shear \\
\hline 148R & 1 & $127-132$ & 952.1 & 1 & OxG & 6.0 & 3 & 46.8 & shear \\
\hline $148 \mathrm{R}$ & 7 & $112-118$ & 960.4 & 1 & OG & 6.7 & 4 & 68.8 & shear \\
\hline $149 \mathrm{R}$ & 2 & $55-60$ & 962.3 & 1 & OG & 7.0 & 2 & 58.7 & shear \\
\hline $150 \mathrm{R}$ & 3 & $65-69$ & 973.2 & 5 & $\mathrm{G}$ & 6.1 & 0 & 71.6 & \\
\hline $150 \mathrm{R}$ & 3 & $77-83$ & 973.4 & 2 & G & 6.0 & 0 & 70.3 & \\
\hline $151 \mathrm{R}$ & 4 & $82-87$ & 984.1 & 1 & $\mathrm{G}$ & 6.2 & 0 & 72.3 & \\
\hline $154 \mathrm{R}$ & 3 & $67-72$ & 1008.8 & 2 & OxG & 6.1 & 1 & 63.1 & \\
\hline $157 R$ & 4 & $66-72$ & 1039.7 & 5 & OG & 6.6 & 0 & 45.1 & \\
\hline $157 R$ & 5 & $134-140$ & 1041.9 & 28 & $\mathrm{OxG}$ & 6.1 & 2 & 31.7 & \\
\hline $159 \mathrm{R}$ & 4 & $84-89$ & 1058.8 & 2 & OG & 7.5 & 0 & 75.1 & \\
\hline $161 R$ & 4 & $26-35$ & 1077.1 & 1 & OG & 6.9 & 1 & 69.1 & \\
\hline $164 \mathrm{R}$ & 3 & $21-29$ & 1102.8 & 1 & OG & 6.2 & 0 & 73.0 & \\
\hline $167 R$ & 6 & $0-6$ & 1127.1 & 1 & $\mathrm{G}$ & 7.1 & 1 & 73.6 & \\
\hline $168 \mathrm{R}$ & 3 & $51-56$ & 1133.3 & 25 & $\mathrm{G}$ & 10.2 & 0 & 69.9 & \\
\hline $170 \mathrm{R}$ & 2 & $65-69$ & 1151.0 & 1 & DOxG & 6.8 & 0 & 72.2 & \\
\hline $173 R$ & 4 & $105-113$ & 1183.7 & 23 & OG & 8.7 & 0 & 100.0 & \\
\hline $173 R$ & 4 & $115-119$ & 1183.8 & 20 & OG & 8.6 & 0 & 74.4 & \\
\hline $173 R$ & 4 & $94-100$ & 1183.6 & 6 & OG & 6.0 & 0 & 71.1 & \\
\hline $177 R$ & 6 & $111-118$ & 1209.6 & 3 & OG & 6.4 & 0 & 73.1 & \\
\hline $180 \mathrm{R}$ & 4 & $109-119$ & 1235.9 & 26 & OG & 8.1 & 0 & 74.6 & \\
\hline $180 \mathrm{R}$ & 4 & $93-100$ & 1235.8 & 5 & OG & 6.4 & 0 & 75.7 & \\
\hline $183 R$ & 2 & $16-25$ & 1261.5 & 1 & OG & 6.5 & 0 & 77.0 & \\
\hline $186 \mathrm{R}$ & 6 & $40-46$ & 1296.2 & 1 & OG & 7.1 & 0 & 76.6 & \\
\hline 190R & 3 & $68-77$ & 1329.8 & & OxG & 6.5 & 1 & 50.9 & \\
\hline 191R & 8 & $31-36$ & 1345.1 & 1 & $\mathrm{OG}$ & 6.6 & 0 & 74.1 & \\
\hline $195 R$ & 4 & $73-79$ & 1368.8 & 1 & TR & 6.3 & 0 & 73.6 & \\
\hline $199 \mathrm{R}$ & 6 & $56-63$ & 1400.3 & 1 & TR & 7.2 & 0 & 76.2 & \\
\hline $202 \mathrm{R}$ & 8 & $72-74$ & 1430.8 & 1 & TR & 5.9 & 0 & 67.9 & \\
\hline
\end{tabular}


Table 2. (continued)

\begin{tabular}{cccccccccc}
\hline Core & $\mathrm{S}$ & Interval, cm & Depth, mbsf & \%Alt & Rock Type & $\delta^{18} \mathrm{O}$ & CP Fabric & Mg\# & Shear/Fault \\
\hline 206R & 4 & $51-57$ & 1464.6 & 1 & OG & 6.5 & 0 & 79.0 & 77.0 \\
209R & 4 & $103-111$ & 1493.7 & 31 & OG & 4.7 & 0 & 77.1 & \\
$209 \mathrm{R}$ & 4 & $63-70$ & 1493.7 & 14 & OG & 4.4 & 0 & \\
\hline
\end{tabular}

${ }^{\mathrm{a}}$ S, section; Alt, alteration (data from Shipboard Scientific Party [1999]); G, gabbro; OG, olivine gabbro; OxG, oxide gabbro; GN, gabbronorite; $\delta^{18} \mathrm{O}$ in per mil SMOW; mbsf, meters below seafloor; DOxG, disseminated oxide gabbro; FV, felsic vein; TR, troctolite; cp, crystal-plastic; classification from Shipboard Scientific Party [1999]; Mg\#, Mg/(Mg + Fe) molar, from Hertogen et al. [2002] and Bach et al. [2001a].

well as low-temperature alteration, are most abundant (Table 1). This contrasts with the amphibolite mylonites at the top of the hole, however, where total alteration is much more intense (up to $100 \%$ ). A second zone of more intense recrystallization in the Leg 176 section is present at $835-1050$ mbsf, where many of the rocks exhibit high-temperature plastic deformation. Below $1050 \mathrm{~m}$, the intensity of alteration is generally only a few percent, associated with veins and microfractures. The deepest interval of the core $(1475-1506 \mathrm{mbsf})$ is characterized by greenschist minerals.

\section{Methods}

[14] Sixty-four whole rock samples from Hole 735B were analyzed for oxygen isotope ratios (Table 2). The samples are mainly a subset of the Leg 176 shipboard XRF powders [Shipboard

Table 3. Stable Isotope Data for Vein Minerals ${ }^{\mathrm{a}}$

\begin{tabular}{|c|c|c|c|c|c|c|c|}
\hline Core-Section & Centimeter Interval & $\mathrm{Pc}$ & Min & Depth, mbsf & $\delta^{18} \mathrm{O}$ & $\delta \mathrm{D}$ & $\delta^{13} \mathrm{C}$ \\
\hline $2 \mathrm{R} 3$ & $40-45$ & 7 & $\mathrm{Hb}$ & 13.99 & 4.4 & -58.0 & \\
\hline 12R1 & $60-62$ & $5 \mathrm{D}$ & $\mathrm{Hb}$ & 40.11 & 4.2 & & \\
\hline $14 \mathrm{R} 3$ & $35-36$ & $2 \mathrm{~A}$ & $\mathrm{Hb}$ & 53.53 & 4.5 & -51.3 & \\
\hline $22 \mathrm{R} 3$ & $119-120$ & $5 \mathrm{~A}$ & $\mathrm{Hb}$ & 99.03 & 3.1 & & \\
\hline $22 \mathrm{R} 3$ & $1-3$ & $1 \mathrm{a}$ & $\mathrm{Hb}$ & 112.02 & 3.8 & -48.4 & \\
\hline $25 \mathrm{R} 2$ & $14-20$ & $2 \mathrm{~A}$ & $\mathrm{Hb}$ & 112.18 & 1.2 & & \\
\hline $25 \mathrm{R} 2$ & $18-20$ & 1 & $\mathrm{Hb}$ & 115.68 & 3.0 & & \\
\hline $26 \mathrm{R} 1$ & $23-26$ & 2 & $\mathrm{Hb}$ & 115.73 & 3.6 & -51.5 & \\
\hline $26 \mathrm{R} 1$ & $116-122$ & 6 & $\mathrm{Hb}$ & 128.73 & 3.8 & & \\
\hline $28 \mathrm{R} 2$ & $68-72$ & $2 \mathrm{~A}$ & $\mathrm{Hb}$ & 151.89 & 3.8 & & \\
\hline $33 \mathrm{R} 2$ & $43-45$ & $3 \mathrm{~A}$ & $\mathrm{Hb}$ & 155.11 & 1.4 & -48.0 & \\
\hline $78 \mathrm{R} 1$ & $1-5$ & $1 \mathrm{~A}$ & $\mathrm{Hb}$ & 409.91 & 4.9 & & \\
\hline $78 \mathrm{R} 1$ & $47-54$ & $5 \mathrm{~A}$ & $\mathrm{Hb}$ & 409.51 & 4.3 & & \\
\hline $81 \mathrm{R} 2$ & $75-80$ & $2 \mathrm{D}$ & $\mathrm{Hb}$ & 434.99 & 5.1 & & \\
\hline 90R3 & $38-42$ & $2 \mathrm{~A}$ & Cumm & 510.87 & 5.1 & & \\
\hline 90R3 & $38-42$ & $2 \mathrm{~A}$ & $\mathrm{Pl}$ & 510.87 & 7.1 & & \\
\hline $90 \mathrm{R} 8^{\mathrm{b}}$ & $103-104$ & & $\mathrm{Ar}$ & 517.07 & 32.6 & & 3.2 \\
\hline $93 \mathrm{R} 1^{\mathrm{b}}$ & $86-87$ & & $\mathrm{Cc}$ & 532.81 & 32.4 & & 3.1 \\
\hline $96 \mathrm{R} 1^{\mathrm{b}}$ & $36-37$ & & $\mathrm{Cc}$ & 549.13 & 31.1 & & 0.3 \\
\hline $99 \mathrm{R} 1^{\mathrm{b}}$ & $113-114$ & & $\mathrm{Cc}$ & 567.24 & 31.9 & & 2.7 \\
\hline $102 \mathrm{R} 3^{\mathrm{b}}$ & $1-2$ & & $\mathrm{Cc}$ & 593.39 & 31.4 & & 2.8 \\
\hline $103 R 4^{b}$ & $72-73$ & & $\mathrm{Cc}$ & 602.11 & 31.2 & & -0.4 \\
\hline $107 \mathrm{R} 1^{\mathrm{b}}$ & $81-86$ & & $\mathrm{Cc}$ & 602.11 & 31.9 & & 2.7 \\
\hline $107 \mathrm{R} 1^{\mathrm{b}}$ & $81-86$ & & $\mathrm{C} / \mathrm{S}$ & 620.31 & 19.9 & & \\
\hline $116 \mathrm{R} 3^{\mathrm{b}}$ & $39-40$ & & $\mathrm{Cc}$ & 674.85 & 31.2 & & -2.7 \\
\hline $118 \mathrm{R} 1^{\mathrm{b}}$ & $8-14$ & & $\mathrm{Sm}$ & 690.88 & 18.3 & & \\
\hline $123 \mathrm{R} 7$ & $1-4$ & $1 \mathrm{~A}$ & Augite & 747.12 & 0.6 & & \\
\hline $133 \mathrm{R} 3$ & $12-16$ & $1 \mathrm{~A}$ & $\mathrm{Hb}$ & 825.70 & 5.1 & -40.5 & \\
\hline $133 \mathrm{R} 7^{\mathrm{b}}$ & $107-111$ & & $\mathrm{Ch}(+\mathrm{Sm})$ & 832.33 & 11.1 & & \\
\hline $172 \mathrm{R} 7^{\mathrm{b}}$ & $132-137$ & & $\mathrm{Ch}+\mathrm{C} / \mathrm{S}$ & 1178.13 & 9.7 & & \\
\hline 179R3 & $146-149$ & $3 \mathrm{~F}$ & $\mathrm{Hb}$ & 1224.64 & 4.3 & & \\
\hline $181 \mathrm{R} 2^{\mathrm{b}}$ & $7-13$ & & Mg-Mont & 1241.70 & 13.2 & & \\
\hline $197 R 2^{b}$ & $34-40$ & & $\mathrm{Ch}+\mathrm{C} / \mathrm{S}$ & 1385.14 & 11.7 & & \\
\hline $202 \mathrm{R} 2^{\mathrm{b}}$ & $135-141$ & & $\mathrm{Ch}(+\mathrm{C} / \mathrm{S})$ & 1423.94 & 7.1 & & \\
\hline $207 \mathrm{R} 5^{\mathrm{b}}$ & $53-57$ & & $\mathrm{C} / \mathrm{S}$ & 1474.90 & 11.6 & & \\
\hline
\end{tabular}

\footnotetext{
${ }^{\mathrm{a}}$ Min, mineral; mbsf, meters below seafloor; Hb, hornblende; Cumm, cummingtonite; Pl, plagioclase; Ar, aragonite; Cc, calcite; Sm, smectite; $\mathrm{Ch}$, chlorite; Mont, montmorillonite; $\mathrm{C} / \mathrm{S}$, chlorite/smectite; minor phases in parentheses. $\delta^{18} \mathrm{O}, \delta \mathrm{D}$ in \%o VSMOW; $\delta^{13} \mathrm{C} \%$ PDB.

${ }^{b}$ From Alt and Bach [2001].
} 


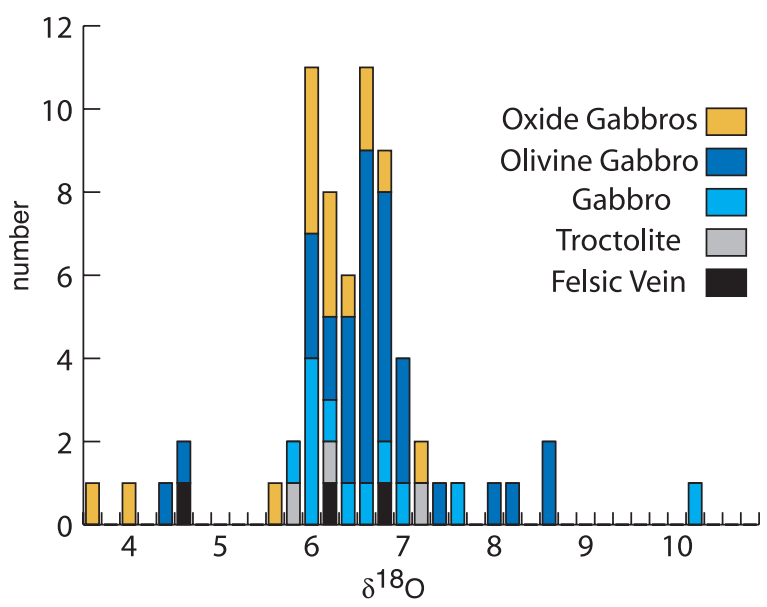

Figure 3. Histogram of whole rock $\delta^{18} \mathrm{O}$ values for the Leg 176 section of Hole 504B. Data from Table 1. Data for some rock types are grouped together: gabbro includes gabbro and gabbronorite; oxide gabbro includes oxide gabbro, disseminated oxide gabbro, and oxide gabbronorite. $\delta^{18} \mathrm{O}$ in per mil SMOW.

Scientific Party, 1999], which were selected to be representative of the various rock and alteration types throughout the Leg 176 section. Table 2 also includes data for rocks affected by late lowtemperature alteration [Alt and Bach, 2001]. Petrographic data, primary and secondary mineral compositions, and bulk geochemical analyses for these samples are given by Shipboard Scientific Party (1999), Hertogen et al. [2002], and Bach et al. [2001a].

[15] Representative minerals separated from veins were analyzed for oxygen and hydrogen isotope compositions. These include various minerals from the Leg 176 section of the core and amphiboles from the Leg 118 section (Table 3).

[16] Oxygen isotope analyses were carried out by reacting samples with $\mathrm{BrF}_{5}$ in externally heated nickel reaction vessels [Clayton and Mayeda, 1963], and converting $\mathrm{O}_{2}$ to $\mathrm{CO}_{2}$ gas by reaction with heated carbon rods. Oxygen isotope ratios were measured using a Finnigan Delta-S mass spectrometer. NBS 28 quartz run with sample unknowns had a mean $\delta^{18} \mathrm{O}$ value of $9.6 \%$ o $( \pm 0.2$, $1 \sigma$ ) compared to the accepted value of $9.58 \%$.

[17] Samples for $\mathrm{H}$ isotope analyses were heated under vacuum at $150^{\circ} \mathrm{C}$ for 4 hours, then fused to drive off water, which was sealed in a quartz tube with $\mathrm{Zn}$ metal. Any $\mathrm{H}_{2}$ gas generated during sample fusion was converted to $\mathrm{H}_{2} \mathrm{O}$ by reaction with hot $\mathrm{CuO}$, and total water was reacted with $\mathrm{Zn}$ at $800^{\circ} \mathrm{C}$ to generate hydrogen gas [Venneman and
O'Neil, 1993]. Isotope measurements were made on a Finnigan delta-S mass spectrometer. NBS 30 Biotite yielded a value of $-61.66 \pm 3.83 \%$ VSMOW $(1 \sigma, \mathrm{n}=19)$ compared to the accepted value of $-65.7 \%$. Data for $\delta \mathrm{D}$ reported in Table 3 have been corrected for this offset.

\section{Results and Discussion}

[18] Oxygen isotope ratios for the Leg 176 whole rocks range from 3.7 to $10.2 \%$, with most values in the range 5.6-7.6\% (Table 2; Figure 3). There are no consistent differences in $\delta^{18} \mathrm{O}$ among the different rock types, although the two lowest values are both for oxide gabbros. Figure 4 shows that there is no correlation of $\delta^{18} \mathrm{O}$ with percent alteration, nor are there clear correlations of $\delta^{18} \mathrm{O}$ values for Leg 176 samples with depth, $\mathrm{Mg}$ number, or intensity of high-temperature crystal-plastic deformation.

\subsection{Primary $\delta^{18} \mathrm{O}$}

[19] MORBs have primary $\delta^{18} \mathrm{O}$ values of $5.7 \pm$ 0.3\%o [Muehlenbachs and Clayton, 1972; Harmon and Hoefs, 1995]. The rocks from Hole 735B are cumulates, but the average composition of this gabbroic section is too evolved to account for associated volcanic rocks, indicating that prior fractionation and removal of more primitive cumulates has occurred deeper in this crustal section

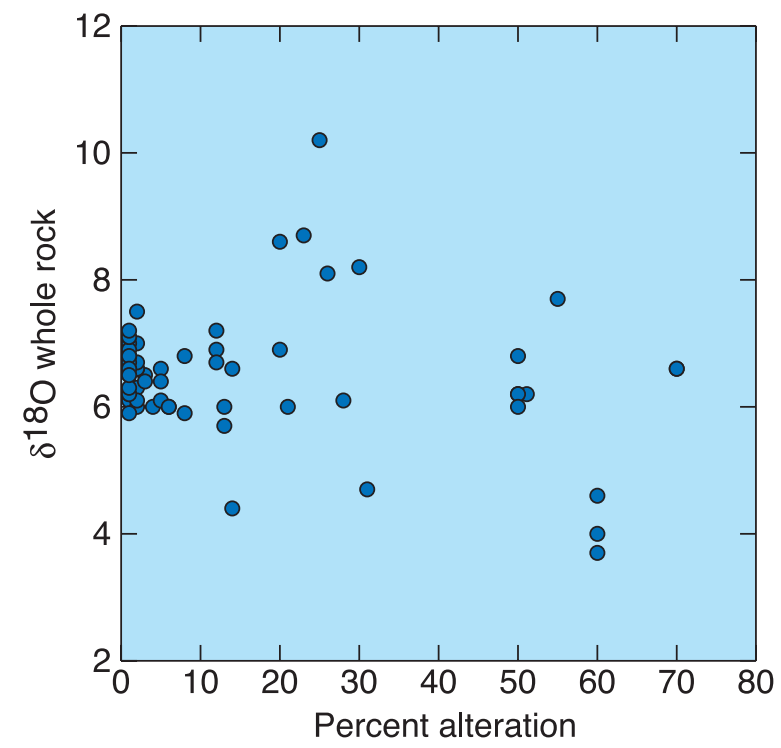

Figure 4. Whole rock $\delta^{18} \mathrm{O}$ versus percent alteration for Leg 176 Hole $735 \mathrm{~B}$ samples. There is no correlation between $\delta^{18} \mathrm{O}$ and percent alteration. Note elevated $\delta^{18} \mathrm{O}$ values for samples having $\sim 1 \%$ alteration. See text for discussion. Data from Table 1. 


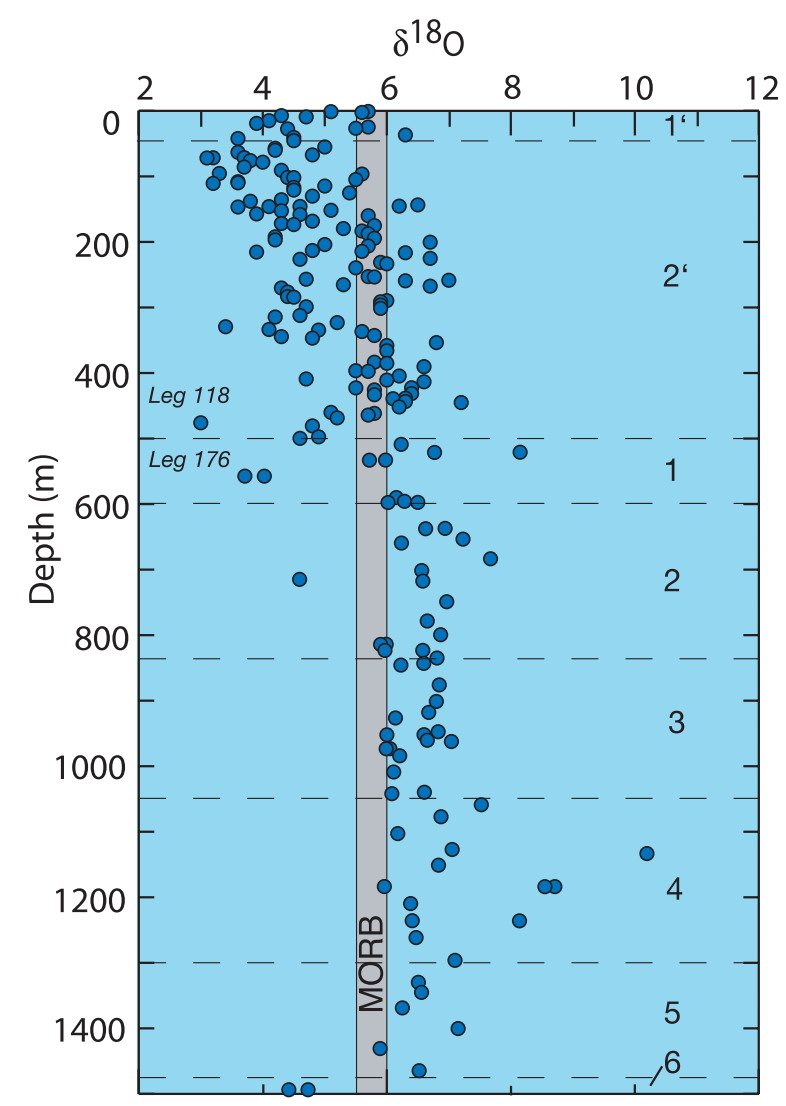

Figure 5. Whole rock $\delta^{18} \mathrm{O}$ versus depth in Hole 735B. The upper $\sim 400 \mathrm{~m}$ is depleted in ${ }^{18} \mathrm{O}$ relative to fresh MORB (shaded band), whereas the deeper kilometer is enriched in ${ }^{18} \mathrm{O}$. See text for discussion. Data for Leg 176 section from Table 2; Leg 118 data from Stakes [1991]. $\delta^{18} \mathrm{O}$ in per mil SMOW. Dashed lines and numbers indicate alteration zones from Table 1 [after Bach et al., 2001a].

[Dick et al., 2000]. The primary oxygen isotope composition of the gabbros from Hole 735B may thus be affected slightly by crystallization and fractionation of low- $\delta^{18} \mathrm{O}$ olivine earlier in the history of magmatic accretion at this site [e.g., Eiler et al., 2000].

[20] The primary isotopic composition of the rocks can be calculated by mass balance, however. Gao et al. [2006] present oxygen isotope compositions of minerals from Leg 176 gabbroic rocks. Clinopyroxene has a $\delta^{18} \mathrm{O}$ value of $5.4 \pm 0.2(\mathrm{n}=21)$, and olivine a value of $5.0 \pm 0.1 \%$, consistent with mantle values for these minerals [Gao et al., 2006; Eiler et al., 2000]. Ignoring one altered low- $\delta^{18} \mathrm{O}$ plagioclase sample $(4 \%)$, plagioclase has $\delta^{18} \mathrm{O}$ of $6.3 \pm 0.2 \%$ o $(1 \sigma, \mathrm{n}=20$ [Gao et al., 2006]). This value is slightly high for basaltic plagioclase and could reflect olivine fractionation, but the oxygen isotope fractionation between olivine and plagioclase from Hole $735 \mathrm{~B}$ is higher than magmatic values from experiments and observed in MORB $(0.65 \pm 0.14 \%$ o [Eiler et al., 2000]). This suggests that post-crystallization exchange of oxygen between plagioclase and seawater fluids has occurred [Gao et al., 2006].

[21] Using the mineral $\delta^{18} \mathrm{O}$ values from Gao et al. [2006] and average modal data for the different rock types recovered from the hole [Hertogen et al., 2002], the gabbroic rocks have primary $\delta^{18} \mathrm{O}$ values of $5.9-6.0 \%$. Adjusting the plagioclase $\delta^{18} \mathrm{O}$ value downward slightly to $6.0 \%$ o to correct for possible alteration effects gives a primary value for the $735 \mathrm{~B}$ rocks of $5.7-5.8 \%$. In any case, the primary $\delta^{18} \mathrm{O}$ values of Hole $735 \mathrm{~B}$ rocks lie within the range for MORB.

\subsection{Depth Profile of $\delta^{18} \mathrm{O}$}

[22] Rocks from the upper $500 \mathrm{~m}$ of Hole 735B from ODP Leg 118 are generally depleted in ${ }^{18} \mathrm{O}$ as the result of interaction with seawater fluids at high temperatures (Figure 5) [Stakes, 1991; Stakes et al., 1991]. This is related to alteration associated with early granulite to amphibolite grade deformation, and to later brittle fracturing, veining, and alteration of the host rocks. The decreasing extent of deformation and hydrothermal alteration with depth (Figure 2; Table 1) is reflected in increasing bulk rock $\delta^{18} \mathrm{O}$ values that eventually scatter about the primary igneous value at 250-400 $\mathrm{m}$ (Figure 5). In contrast to the upper $500 \mathrm{~m}$, bulk rocks in the Leg 176 section of the hole (500-1500 mbsf) mostly have $\delta^{18} \mathrm{O}$ values in the range $5.6-7.6 \%$, with a few higher and lower values scattered throughout the core (Figure 5). In the following sections, the different processes resulting in the observed $\delta^{18} \mathrm{O}$ values of the rocks are discussed.

[23] The interval from $\sim 500$ to $600 \mathrm{mbsf}$ is characterized by early high-temperature deformation and alteration with concomitant formation of amphibole and secondary plagioclase, but also by intense fracturing in the vicinity of late brittle faults. Low-temperature alteration phases such as smectite, calcite, and iron oxyhydroxides are common associated with this brittle fracturing. The presence of open fractures suggests that this zone may still be hydrologically active [Shipboard Scientific Party, 1999; Dick et al., 2000], and $\delta^{18} \mathrm{O}$ values of $31-32 \%$ for carbonates indicate temperatures as low as $\sim 10^{\circ} \mathrm{C}$ (Table 3) [Alt and Bach, 2001]. Rocks from this interval thus contain abundant effects of high- and low-temperature alteration 
and serve to illustrate the influence of these effects on the whole rock $\delta^{18} \mathrm{O}$ values throughout the Leg 176 section of Hole 735B.

[24] Figure 6 shows how varying hydrothermal alteration processes can affect the oxygen isotope composition of gabbros. In these examples, as seawater reacts with rock at elevated temperatures $\left(400-600^{\circ} \mathrm{C}\right)$ to form amphibole and plagioclase, the rock is depleted in ${ }^{18} \mathrm{O}$. Depending on the relative mass of rock and fluid (the water/rock ratio), the rocks can exhibit varying ${ }^{18} \mathrm{O}$ depletions relative to fresh gabbro. The calculation for Figure 6 assumes that the entire rock is in equilibrium with the fluid, but in reality gabbros from Hole 735B (and seafloor rocks in general) are typically only partly recrystallized. In such a rock, the calculations shown in Figure 6 only give the oxygen isotope composition of the altered material,
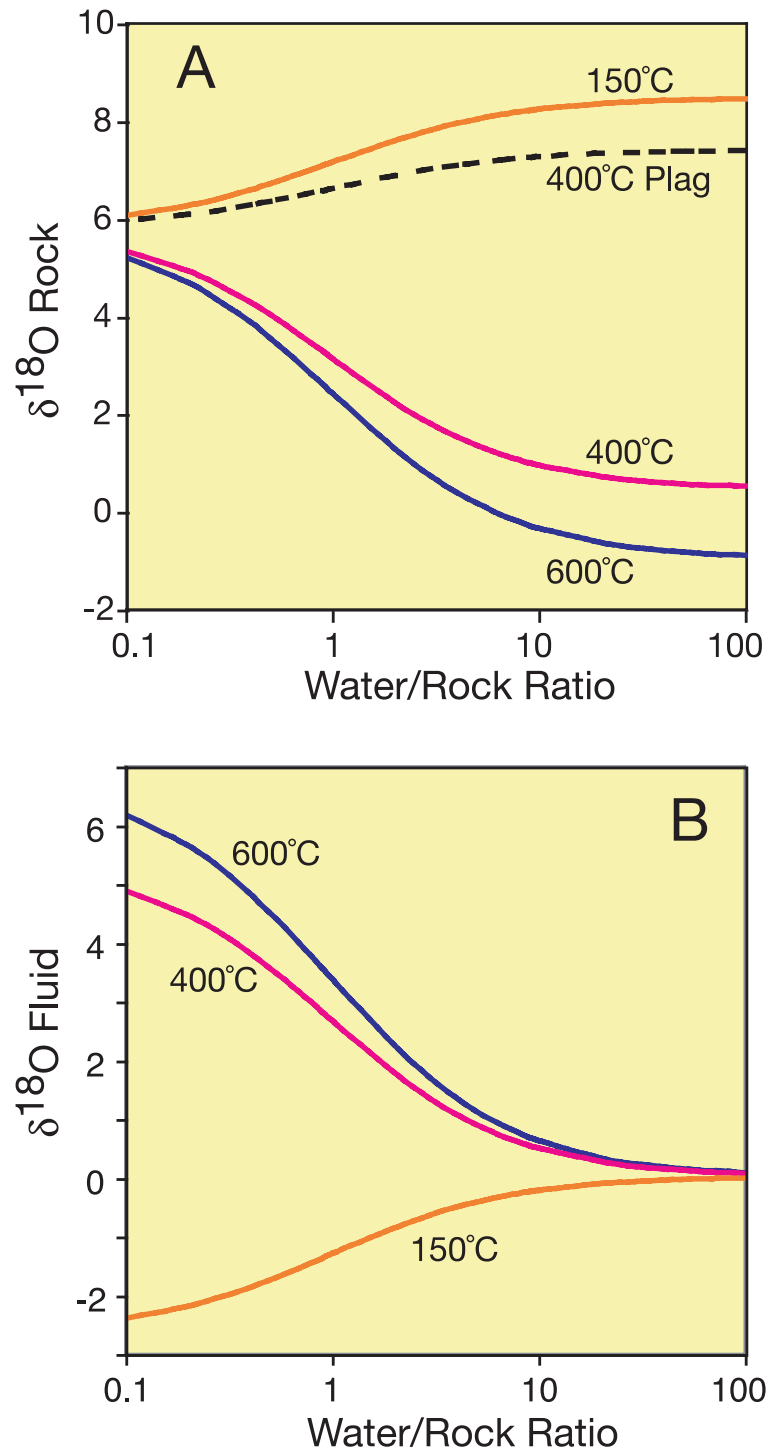

whereas the remaining portion of the rock retains its igneous composition, so the bulk rock $\delta^{18} \mathrm{O}$ reflects a mixture of secondary and primary phases. Thus varying proportions of primary and secondary minerals can contribute to a range of ${ }^{18} \mathrm{O}$ depletions of the rocks. In contrast to these examples, reaction of seawater with the rocks at lower temperatures will result in ${ }^{18} \mathrm{O}$ enrichment of the rock, as shown by reaction of gabbro to chlorite + albite at $150^{\circ} \mathrm{C}$ in Figure 6.

[25] Concomitant with ${ }^{18} \mathrm{O}$ depletion of the rock at high temperatures is a corresponding ${ }^{18} \mathrm{O}$ enrichment of the seawater-derived fluid (Figure 6). As seawater penetrates downward and reacts with the crust, the fluid becomes enriched in ${ }^{18} \mathrm{O}$, so lower crustal rocks can react with seawater $\left(\delta^{18} \mathrm{O}=0 \%\right)$ or with ${ }^{18} \mathrm{O}$ enriched hydrothermal fluids. If fluids are sufficiently enriched in ${ }^{18} \mathrm{O}$, hydrothermal recrystallization of plagioclase at elevated temperatures can produce ${ }^{18} \mathrm{O}$ enrichment of the altered rock (Figure 6). Reaction at lower temperatures with ${ }^{18} \mathrm{O}$ enriched hydrothermal fluids will produce even greater ${ }^{18} \mathrm{O}$ enrichments. Specific examples of these effects in rocks from Hole 735B are presented below.

[26] A sample from $557 \mathrm{~m}$ in Hole $735 \mathrm{~B}$ has a $\delta^{18} \mathrm{O}$ value of $3.9 \%$, reflecting extensive hydrothermal recrystallization to secondary plagioclase (34\%), amphibole (23\%), and minor ( $3 \%)$ diop-

Figure 6. Calculations illustrating effects of waterrock interactions on oxygen isotope compositions of rocks and fluids. Plots are based on water-rock interaction calculations of Taylor [1977]: $(\mathrm{W} / \mathrm{R})_{\mathrm{A}}=$ $\left(\delta_{\mathrm{r}}^{\mathrm{f}}-\delta_{\mathrm{r}}^{\mathrm{i}}\right) /\left(\delta_{\mathrm{w}}^{\mathrm{i}}-\delta_{\mathrm{w}}^{\mathrm{f}}\right)$, where $(\mathrm{W} / \mathrm{R})_{\mathrm{A}}$ is the atomic water/ rock ratio in a closed system, $\delta_{\mathrm{r}}^{\mathrm{i}}$ and $\delta_{\mathrm{r}}^{\mathrm{f}}$ are the initial and final rock $\delta^{18} \mathrm{O}$ values, respectively, and $\delta_{\mathrm{w}}^{\mathrm{i}}$ and $\delta_{\mathrm{w}}^{\mathrm{f}}$ are the initial and final fluid $\delta^{18} \mathrm{O}$ values. Solid lines in Figures $6 \mathrm{a}$ and $6 \mathrm{~b}$ indicate rock and fluid $\delta^{18} \mathrm{O}$ as a function of W/R for reaction of gabbro $\left(\delta_{\mathrm{r}}^{\mathrm{i}}=5.8 \% \mathrm{o}\right)$ with seawater $\left(\delta_{\mathrm{w}}^{\mathrm{i}}=0 \% \mathrm{c}\right)$ at different temperatures. Dashed line in Figure $6 a$ shows effect of recrystallization of igneous plagioclase assuming reaction with ${ }^{18} \mathrm{O}$ enriched hydrothermal fluid $\left(\delta_{\mathrm{w}}{ }^{\mathrm{i}}=5 \%\right)$ at $400^{\circ} \mathrm{C}$. Altered rock at $400^{\circ}$ and $600^{\circ} \mathrm{C}$ is approximated by $50 \%$ plagioclase $\left(\mathrm{An}_{30}\right)$ plus $50 \%$ amphibole, using plagioclase-water oxygen isotope fractionation from $\mathrm{O}$ 'Neil and Taylor [1967] and amphibole-water fractionation calculated from amphibole-quartz and quartz-water fractionations of Bottinga and Javoy [1975] and Sharp and Kirschner [1994]. Altered rock at $150^{\circ} \mathrm{C}$ is approximated by $50 \%$ chlorite plus $50 \%$ albite, using albite-water and chlorite-water fractionations from O'Neil and Taylor [1967] and Wenner and Taylor [1971]. 
side [Shipboard Scientific Party, 1999]. Equilibrium temperatures and fluid compositions were calculated using mineral-water oxygen isotope fractionations for these phases [O'Neil and Taylor, 1967; Matthews et al., 1983]. Amphibole-water fractionation was calculated from amphibole-quartz and quartz-water fractionations of Bottinga and Javoy [1975] and Sharp and Kirschner [1994]. The calculations assume that the unaltered $40 \%$ of the rock has $\delta^{18} \mathrm{O}=5.8 \%$ and does not exchange oxygen with fluids. If the interacting fluid had seawater oxygen isotope composition $\left(\delta^{18} \mathrm{O}=\right.$ $0 \%$ ), the secondary mineral assemblage would be in equilibrium with the fluid at a temperature of $\sim 500^{\circ} \mathrm{C}$, but if fluids were enriched in ${ }^{18} \mathrm{O}$ the temperature was higher (i.e., $600-700^{\circ} \mathrm{C}$ for fluid $\delta^{18} \mathrm{O}=1-2 \%$ ). In contrast, a sample at $521 \mathrm{~m}$ having a $\delta^{18} \mathrm{O}$ value of $8.2 \%$ was affected by hydrothermal alteration and contains amphibole, but the amount of this alteration is slight (only $2 \%$ ). The secondary mineralogy of this sample is dominated by low-temperature alteration, which resulted in 28\% recrystallization to chloritesmectite and calcite. These phases have $\delta^{18} \mathrm{O}$ values of $7-20 \%$ and $31-32 \%$, respectively (Table 3) [Alt and Bach, 2001], and it is their presence that causes the ${ }^{18} \mathrm{O}$-enrichment of this sample. The remaining samples in the 500-600 m interval contain variable proportions of high- and low-temperature alteration products and have $\delta^{18} \mathrm{O}$ values of $5.7-6.5 \%$. Thus major controls on bulk rock $\delta^{18} \mathrm{O}$ values (Figure 5) include the intensity of recrystallization and the relative proportions of high- versus low-temperature alteration minerals in the rocks.

[27] Another major influence on the oxygen isotope compositions of the Leg 176 rocks is suggested by data shown in Figure 4. Many samples contain only $\sim 1 \%$ secondary phases as determined by petrographic microscopy, yet these rocks have $\delta^{18} \mathrm{O}$ values that range from unaltered $(5.9-6.0 \%$ ) up to $7.5 \%$. A reasonable explanation for this is hydrothermal recrystallization of plagioclase and exchange of oxygen isotopes between plagioclase and hydrothermal fluids. This has been shown to occur in other seafloor gabbros where no petrographic evidence for recrystallization of plagioclase is observed and plagioclase retains igneous compositions [e.g., Gregory and Taylor, 1981; Stakes, 1991; Lecuyer and Gruau, 1996; FruhGreen et al., 1996]. Additional evidence for this process comes from $\delta^{18} \mathrm{O}$ values of plagioclase separates from whole rocks and from in situ analyses of cumulate plagioclase from Hole
735B: these data reveal $\delta^{18} \mathrm{O}$ values ranging up to $7.4 \%$ in the deeper $1 \mathrm{~km}$ of the core [Gao et al., 2006], although ${ }^{18} \mathrm{O}$ depletions of plagioclase (to $3.0 \%$ ) are also common in the upper $500 \mathrm{~m}$ [Stakes, 1991].

[28] Deeper in the hole, three samples from 1130 $1240 \mathrm{~m}$ are highly enriched in ${ }^{18} \mathrm{O}$, having $\delta^{18} \mathrm{O}$ values of $8.1-10.2 \%$. These samples contain little or no high-temperature hydrothermal phases and are dominated by chlorite-smectite, smectite, quartz, and calcite, which all have high $\delta^{18} \mathrm{O}$ values (Table 3 ) and formed late, at relatively low temperatures $\left(<200^{\circ} \mathrm{C}\right)$ [Alt and Bach, 2001].

[29] In contrast, the two deepest samples at $1493 \mathrm{~m}$ have $\delta^{18} \mathrm{O}$ values of $4.2-4.7 \%$ and lie in a zone where greenschist minerals are abundant and there are little or no effects of low-temperature $\left(<150^{\circ} \mathrm{C}\right)$ alteration (Table 1) [Dick et al., 2000; Bach et al., 2001a]. These two samples are $14-30 \%$ altered to amphibole, chlorite, and zeolite.

\subsection{Faults and Shear Zones}

[30] Because deformation is critical to provide pathways for penetration of fluids into the lower oceanic crust, it is of interest to examine stable isotope evidence for fluid interactions in rocks deformed by high-temperature ductile and lowertemperature brittle processes. The interval from $500-600 \mathrm{~m}$ is characterized by high-temperature plastic deformation but also by abundant brittle fracturing associated with faults. As discussed above, the rocks contain variable amounts of highand low-temperature alteration phases and consequently exhibit variable ${ }^{18} \mathrm{O}$-enrichments and depletions. The isotope and petrographic data for this interval illustrate that zones of deformation acted as pathways for seawater-derived fluids to enter the lower crust over a range of conditions throughout the history of the site.

[31] Deeper in the basement, a gabbro mylonite associated with high-temperature shearing at $701 \mathrm{~m}$ is highly altered to amphibole (23\%), plagioclase (43\%), and minor chlorite-smectite (4\%) [Shipboard Scientific Party, 1999]. This sample has a $\delta^{18} \mathrm{O}$ value of $6.6 \%$, indistinguishable from the surrounding rocks (Table 2, Figure 5). The small amount of smectite-chlorite present is insufficient to account for the ${ }^{18} \mathrm{O}$-enrichment of the rock (e.g., Table 3 ). The secondary mineralogy and high bulk $\delta^{18} \mathrm{O}$ value suggest equilibration with hydrothermal fluids enriched in ${ }^{18} \mathrm{O}$ over seawater values. Calculations using plagioclase-water and 
amphibole-quartz/quartz-water fractionations [O'Neil and Taylor, 1967; Bottinga and Javoy, 1975; Sharp and Kirschner, 1994] show that at temperatures of $400-600^{\circ} \mathrm{C}$ fluids in equilibrium with plagioclase $\left(\mathrm{An}_{30}\right)$ plus amphibole in the rock would have $\delta^{18} \mathrm{O}=1-5 \%$.

[32] Five samples across a shear zone at 947$964 \mathrm{~m}$ are variably altered $(<1 \%$ up to $50 \%)$ and have $\delta^{18} \mathrm{O}$ values of $6.0-7.0 \%$ (Table 2; Figure 5), indistinguishable from the values for overlying and underlying rocks. The more altered rocks contain $\sim 45 \%$ secondary plagioclase, $5 \%$ amphibole, and $<1 \%$ chlorite [Shipboard Scientific Party, 1999]. At temperatures above $400^{\circ} \mathrm{C}$, fluids in equilibrium with plagioclase plus amphibole in the rock would have $\delta^{18} \mathrm{O}$ of $5 \%$ or greater.

[33] From these examples it is clear that fluids enriched in ${ }^{18} \mathrm{O}$ compared to seawater were involved in metamorphism of high-temperature shear zones. Reaction of undeformed rocks with ${ }^{18} \mathrm{O}-$ enriched fluids is documented above, as well. Thus reaction of rocks with ${ }^{18} \mathrm{O}$-enriched fluids is another major influence on the ${ }^{18} \mathrm{O}$-enrichment of the Leg 176 plutonic section. Such fluids may be derived from seawater that had previously reacted with basalt or gabbro at hydrothermal temperatures $\left(>250^{\circ} \mathrm{C}\right)$, perhaps shallower in the crust as fluids penetrated generally downward. Hydrogen isotope evidence presented below, as well as trace element data [Bach et al., 2001b], suggest that some early hydrothermal fluids at Site 735 contained a component of ${ }^{18} \mathrm{O}$-rich magmatic water (see "Vein Minerals" below).

[34] There are no clear differences in $\delta^{18} \mathrm{O}$ between the shear zones and surrounding rocks. Cryptic alteration and isotope exchange with plagioclase in surrounding rocks may have occurred via similar ${ }^{18} \mathrm{O}$-enriched hydrothermal fluids or by seawater fluids at lower temperatures. Any differences that may have existed as the result of alteration at high temperatures during shearing are obscured by continued alteration of rocks to varying degrees under changing conditions (e.g., decreasing temperature).

[35] Syntectonic differentiation of gabbros led to migration of late iron-rich melts into shear zones, and these oxide-rich zones commonly exhibit hightemperature crystal-plastic and later brittle-ductile deformation [Dick et al., 2000]. These zones acted to focus fluid flow as the crustal section cooled and fluid compositions evolved. This can be seen in the wide range of $\delta^{18} \mathrm{O}$ values of oxide gabbros in Figure $3(3.9-7.2 \%$ ). Because iron oxides are depleted in ${ }^{18} \mathrm{O}$ relative to silicates at magmatic temperatures, fresh oxide-rich gabbros can have lower $\delta^{18} \mathrm{O}$ values than the average fresh gabbro. The lowest $\delta^{18} \mathrm{O}$ values for oxide gabbros $(\sim 4 \%$ ), however, cannot be accounted for by concentration of iron oxides, plus these rocks are highly deformed and hydrothermally altered $(\sim 60 \%$ recrystallized). Because of the low $\delta^{18} \mathrm{O}$ values for magnetite, the elevated $\delta^{18} \mathrm{O}$ values for many other oxide gabbros clearly require reaction of these rocks with ${ }^{18} \mathrm{O}$-enriched hydrothermal fluids and/ or lower-temperature fluids. Thus the variation in $\delta^{18} \mathrm{O}$ values of oxide gabbros indicates that these rocks were affected by a wide range of processes and may have served to focus fluid flow locally.

[36] The felsic veins formed from late magmatic hydrous melts, but are overprinted by retrograde hydrothermal alteration [Vanko and Stakes, 1991; Shipboard Scientific Party, 1999]. For example, late magmatic amphibole and phlogopite in felsic veins are commonly partly altered to actinolite, chlorite and smectite. Thus these felsic veins were pathways for late magmatic hydrous melts and fluids, but also for hydrothermal fluids throughout the history of the crustal section. This is also reflected in the range of $\delta^{18} \mathrm{O}$ values of felsic veins (4.6-6.9\%o).

\subsection{Vein Minerals}

[37] Alteration of the rocks proceeds by reaction with hydrothermal fluids that gain access to the rocks via fractures, so secondary minerals filling veins can provide a record of the fluids that have reacted with the rocks. Stable isotope analyses of vein minerals yield evidence for evolution of hydrothermal fluids, from late magmatic fluids, to evolved seawater hydrothermal fluids and late cold seawater.

[38] Fourteen new analyses of vein amphiboles from the Leg 118 section of Hole $735 \mathrm{~B}$ have $\delta^{18} \mathrm{O}$ values of $1.2-5.1 \%$ (Table 3 ), similar to the range of previous values for 8 amphibole veins plus 27 amphiboles separated from bulk rocks from the Leg 118 section (1.6-5.4\%o [Stakes, 1991; Kempton et al., 1991]. In the Leg 176 section, two vein hornblendes and one cummingtoniteactinolite from a felsic vein have $\delta^{18} \mathrm{O}$ values of 4.6-5.4\% (Table 3). Six vein hornblendes in Table 3 have $\delta \mathrm{D}$ values of -40.5 to $-58.0 \%$, similar to $\delta \mathrm{D}$ values of -43 to $-63 \%$ o for amphiboles from 2 veins and separated from 14 rocks from the Leg 118 section of the hole [Stakes, 1991; Kempton et al., 1991]. The higher $\delta \mathrm{D}$ values are 


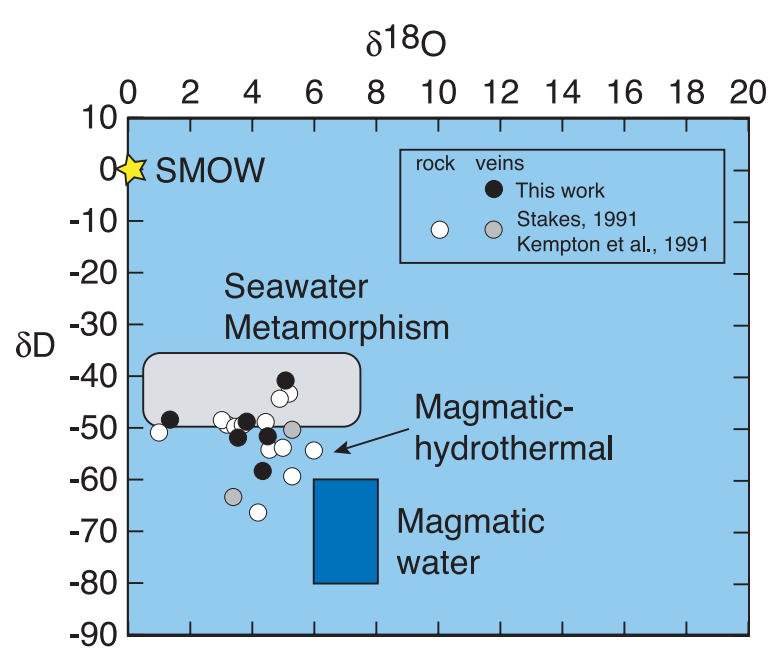

Figure 7. Oxygen and hydrogen isotope compositions of hornblende veins from Hole 735B. The low $\delta \mathrm{D}$ values of many hornblende veins are consistent with formation from fluids containing a component of magmatic water ("Magmatic-hydrothermal"; see text for discussion). Magmatic water field from Taylor and Sheppard [1986]. "Seawater metamorphism" field calculated using hornblende-water fractionation of Suzuoki and Epstein [1976] at $400-500^{\circ} \mathrm{C}$. Data from Table 2, Stakes [1991], and Kempton et al. [1991].

consistent with seawater hydrothermal fluids at $400-500^{\circ} \mathrm{C}$, whereas more negative values $(<-50 \%$ ) suggest a component of magmatic water in vein-forming fluids (Figure 7) [Stakes, 1991]. With the exception of rare late actinolite, the REE compositions of vein amphiboles are similar to those of intergranular magmatic amphiboles, consistent with a magmatic component in vein fluids [Bach et al., 2001b]. The negative fractionation between diopside and water at temperatures below $800^{\circ} \mathrm{C}\left(-1.3 \%\right.$ at $600^{\circ} \mathrm{C}$ [Matthews et al., 1983]) and the low $\delta^{18} \mathrm{O}$ of augite from a vein at $747 \mathrm{~m}$ $(0.6 \%)$ indicate the presence of ${ }^{18} \mathrm{O}$-enriched, evolved seawater fluids or fluids having a magmatic component.

[39] Other data for rocks from the shallower, Leg 118 section of Hole 735B also indicate the presence of magmatic fluids. Fluids released at temperatures of $600-1000^{\circ} \mathrm{C}$ from fluid inclusions in olivine and plagioclase contain magmatic fluids [Kelley, 1996; Kelley and Fruh-Green, 1999, 2001]. Initial fluids exsolved from the cooling magmas were $\mathrm{CO}_{2}$-rich vapors, evolving to more $\mathrm{H}_{2} \mathrm{O}$ rich fluids. During cooling, the fluids respeciated at $\sim 500-800^{\circ} \mathrm{C}$ to produce $\mathrm{CO}_{2}+\mathrm{CH}_{4}+$ $\mathrm{H}_{2} \mathrm{O}$ fluids in conjunction with graphite precipitation. These fluids had bulk $\delta^{13} \mathrm{C}$ values of $-7.6 \%$
( $\pm 6.1 \%$ ) , consistent with magmatic $\mathrm{CO}_{2}$, and $\delta \mathrm{D}$ values of -33 to $-89 \%$ for $\mathrm{H}_{2} \mathrm{O}$ (mean $=-43 \pm$ $6 \%$ ), generally elevated compared to values of -65 to $-80 \%$ considered to be primary magmatic values for water in MORB [Taylor and Sheppard, 1986].

[40] Magmatic fluids may be a common component in hydrothermally altered seafloor gabbros. Low $\delta$ D values, similar to those from Hole 735B, are reported for amphiboles from gabbros at Hess Deep and interpreted to result from the presence of magmatic fluids [Fruh-Green et al., 1996]. Quantifying the amount of magmatic fluid present and the extent of its influence is problematic, however. Gabbros from Hole 735B commonly contain various generations of amphibole: magmatic hornblende, hydrothermal hornblende, and retrograde actinolite, so amphibole separates can reflect a mixture of hydrothermal fluids. Dehydration of hydrothermally altered rock by contact metamorphism related to gabbro intrusion could also influence $\delta \mathrm{D}$ values of fluids. The number of amphibole analyses from the lower $1 \mathrm{~km}$ of the hole is extremely limited, making any estimate of the amount of magmatic fluid influence on this section of the core uncertain. Assuming the data in Figure 7 are representative of amphiboles throughout the $1.5 \mathrm{~km}$ section, however, suggests that hydrothermal fluids containing a magmatic component may exert a significant influence on alteration of the lower crust. The total amount of crust affected by these fluids, however, is small (Table 1).

[41] Data for other veins from Hole 735B indicate formation at lower temperatures and from evolved, ${ }^{18} \mathrm{O}$-enriched seawater-derived hydrothermal fluids. Plagioclase from a felsic vein at $511 \mathrm{~m}$ has $\delta^{18} \mathrm{O}=7.4 \%$, consistent with formation from seawater or evolved seawater $(+2 \%$ ) at temperatures of $250-350^{\circ} \mathrm{C}$ [O'Neil and Taylor, 1967]. Temperatures could have been higher if fluids were more enriched in ${ }^{18}$ O. Stakes [1991] shows that plagioclase-diopside veins from the upper $500 \mathrm{~m}$ of the core formed at temperatures of $250-600^{\circ} \mathrm{C}$ from fluids ranging from seawater $\delta^{18} \mathrm{O}(0 \%)$ up to $5 \%$. Gao et al. [2006] report $\delta^{18} \mathrm{O}$ values of $4.0-6.5 \%$ or plagioclase within gabbros from the Leg 176 section, with the highest values $(>\sim 6.2 \%$ ) interpreted to reflect exchange with fluids at temperatures less than $250^{\circ} \mathrm{C}$.

[42] Later chlorite, chlorite-smectite, and smectite veins have high $\delta^{18} \mathrm{O}$ values, $7.1-19.9 \%$ (Table 3 ). Temperatures of $150-250^{\circ} \mathrm{C}$ are reasonable for formation of the chlorite-rich veins, so assuming 
these temperatures and using the chlorite-water fractionation of Wenner and Taylor [1971], the $\delta^{18} \mathrm{O}$ values of the chlorite-rich phyllosilicates (7.1-11.7\%; Table 3) imply formation from evolved, ${ }^{18} \mathrm{O}$-enriched fluids. This is consistent with rock-dominated ${ }^{87} \mathrm{Sr} /{ }^{86} \mathrm{Sr}$ ratios of $0.70312-$ 0.70492 for phyllosilicate veins [Alt and Bach, 2001; Bach et al., 2001a]. Carbonate veins have high $\delta^{18} \mathrm{O}$ values $(31.2-32.6 \%$; Table 3$)$ and high $\mathrm{Sr}$ isotope ratios (mostly $0.70865-0.70891$ ) indicating formation from seawater at low temperatures ( $10^{\circ} \mathrm{C}$ [Alt and Bach, 2001]). Late, low-temperature alteration related to these fluids also results in addition of alkalis, $\mathrm{H}_{2} \mathrm{O}, \mathrm{C}, \mathrm{U}, \mathrm{P}$, and ${ }^{87} \mathrm{Sr}[$ Bach et al., 2001b].

\subsection{Bulk $\delta^{18} \mathrm{O}$ of the Hole 735B Lower Crustal Section}

[43] Understanding the mechanisms of seawater penetration into the lower crust and identifying fluid compositions are important, but evaluating the net effect of these alteration processes on the bulk $\delta^{18} \mathrm{O}$ of the lower crust is also a major objective. The mean $\delta^{18} \mathrm{O}$ value for the Leg 176 section $(500-1500 \mathrm{mbsf})$ of Hole $735 \mathrm{~B}$ is $6.5 \pm$ $1.0 \%$. Clearly the effects of ${ }^{18} \mathrm{O}$-enriched fluids and late, low-temperature alteration dominate in this section of the hole. Data in Table 1 can be used to estimate whether either of these processes dominates the ${ }^{18} \mathrm{O}$-enrichment of the Leg 176 section. The proportions of high- and low-temperature alteration are similar at 500-600 and 10501506 mbsf (zones 1 and 4-6), whereas hightemperature alteration predominates from $600-$ 1050 mbsf (zones 2 and 3). Zone 3 contains abundant effects of high-temperature crystal-plastic deformation involving ${ }^{18} \mathrm{O}$-enriched fluids, suggesting that the influence of such fluids at high temperatures may be somewhat greater than lowtemperature alteration in producing the net ${ }^{18} \mathrm{O}$ enrichment of the Leg 176 section.

[44] In contrast to the ${ }^{18} \mathrm{O}$-enrichment of the Leg 176 section, the average $\delta^{18} \mathrm{O}$ for 129 samples from the upper $500 \mathrm{~m}$ of the hole is $5.1 \pm 1.0 \%$ o [Stakes et al., 1991]. Although ${ }^{18} \mathrm{O}$-enriched seawater-derived fluids were present in this zone, the rocks are dominated by the effects of high-temperature seawater-dominated fluids and ${ }^{18} \mathrm{O}$-deletion compared to fresh gabbro. The weighted average for the Leg 118 plus Leg 176 sections is 6.0\%o, possibly slightly enriched in ${ }^{18} \mathrm{O}$ but essentially indistinguishable from the primary igneous value for basaltic crust.
[45] Veins make up 1\% of the Leg 176 Hole $735 \mathrm{~B}$ core by volume. Using the vein abundances from Dick et al. [2000] and oxygen isotope ratios of vein minerals [Stakes et al., 1991; Alt and Bach, 2001] (Table 3) gives a weighted average $\delta^{18} \mathrm{O}$ for vein minerals of $7.4 \%$. Adding $1 \%$ of this vein material to the whole-rock average for the entire section has an insignificant effect, increasing the $\delta^{18} \mathrm{O}$ value by only $0.01 \%$. Hence, because the abundance of vein minerals is so small, they have no net effect on the bulk $\delta^{18} \mathrm{O}$ value of the Hole $735 \mathrm{~B}$ section.

\subsection{Seawater Penetration and the Oxygen Isotope Composition of the Lower Oceanic Crust}

[46] Spreading rates of mid-ocean ridges vary, and there is a general change from major faulting and tectonism at slow spreading rates to fewer and smaller faults at fast spreading rates [Carbotte and Scheirer, 2004]. Hydrothermal effects in the lower crust generally appear to correlate with tectonic effects and spreading rate, with metamorphism related to high-temperature plastic deformation common in lower crust generated at slow spreading ridges, and hydrothermal alteration dominated by the presence of brittle cooling fractures in crust formed at fast spreading rates [Ito and Clayton, 1983; Mevel and Cannat, 1991; Gillis, 1995; Fruh-Green et al., 1996; Manning et al., 2000; Wilson et al., 2006]. Because of the variability of tectonic effects within sections of lower crust it is important to compare the results from Hole $735 \mathrm{~B}$ to other lower crustal sections formed at similar and different spreading rates. This is done in the following sections, with reference to other oceanic and ophiolitic lower crustal sections.

\subsubsection{Oceanic Crust}

[47] Other oceanic plutonic sections exhibit oxygen isotope profiles that show the same effects of variable ${ }^{18} \mathrm{O}$-enrichments and depletions as seen in Hole 735B. However, the overall impact of these processes on the isotope composition of the lower crust at these other sites differs from Hole 735B.

[48] Mineral data for plutonic rocks from the Cayman Trough, which formed at a slow spreading rate, illustrate hydrothermal effects that generally diminish downward [Ito and Clayton, 1983]. Gabbroic rocks from the upper $200 \mathrm{~m}$ of the section contain $10-30 \%$ amphibole, and plagioclase in these rocks has $\delta^{18} \mathrm{O}$ values of 2.6-5.4\% , indicating extensive hydrothermal alteration by seawater [Ito and Clayton, 1983]. Amphibole contents of the 
rocks in the deeper $\sim 500 \mathrm{~m}$ are mostly less than $1 \%$, and plagioclase $\delta^{18} \mathrm{O}$ values generally increase downward to igneous values of $5.5-5.8 \%$, indicating much less high-temperature interaction with seawater at greater depths. However, ${ }^{18} \mathrm{O}$-depleted plagioclase (to $4.4 \%$ ) is also common in the deeper zone, providing evidence that seawater locally penetrated and reacted with the rocks at hydrothermal temperatures at these depths. Local slight ${ }^{18} \mathrm{O}$ enrichments of plagioclase (to 6.4\%o) are also present as the result of lower-temperature interactions with seawater in this deeper interval. Overall, however, plagioclase exhibits a net depletion in ${ }^{18} \mathrm{O}$, indicating a slight net depletion in ${ }^{18} \mathrm{O}$ for the plutonic section.

[49] Macquarie Island has been termed an ophiolite [e.g., Cocker et al., 1982], but the island comprises uplifted oceanic crust formed at a mid-ocean ridge [Varne et al., 2000]. The crust has been uplifted in situ and has not been transported, fragmented, or obducted, so it is considered here as uplifted oceanic crust rather than as an ophiolite, which typically form in marginal basins and are subjected to obduction processes. Oxygen isotope data for this section of uplifted oceanic crust are given by Cocker et al. [1982]. Although there are few data through the plutonic section, the rocks exhibit ${ }^{18} \mathrm{O}$ depletions throughout. Four massive gabbros in the upper $\sim 500 \mathrm{~m}$ have $\delta^{18} \mathrm{O}$ values of $3.6-5.7 \%$ o (mean $=4.3 \% \pm 1.4$ ), whereas 6 gabbroic rocks through the lower $\sim 2 \mathrm{~km}$ have values of $4.1-5.3 \%$ $($ mean $=4.5 \% 0 \pm 0.4)$.

[50] At Hess Deep, a complete crustal section formed at a fast spreading rate on the East Pacific Rise has been tectonically exposed by the westward propagating Galapagos rift. Although formed at a fast spreading rate, $\mathrm{O}$ and $\mathrm{H}$ isotope systematics indicate processes similar to those at Site 735: early fluids having a magmatic water component, seawater-derived hydrothermal fluids, and later lower-temperature (greenschist and lower grade) alteration [Fruh-Green et al., 1996]. Here, ODP Hole $894 \mathrm{G}$ penetrates $\sim 150 \mathrm{~m}$ of gabbros, which are interpreted to be within the uppermost plutonic section [Natland and Dick, 1996]. Thirty-two whole rocks from this core, selected to be free of retrograde effects, have $\delta^{18} \mathrm{O}$ values of $2.2-6.5 \%$ o (mean $=4.9 \pm 0.7 \%$ [Lecuyer and Gruau, 1996]). Fruh-Green et al. [1996], however, show that alteration at greenschist and lower grades results in common ${ }^{18} \mathrm{O}$ enrichments of plagioclase and whole rocks, so the net $\delta^{18} \mathrm{O}$ value for the section depends on the proportion of high-temperature
${ }^{18} \mathrm{O}$-depletion and retrograde ${ }^{18} \mathrm{O}$-enrichment. Isotropic upper gabbros from Hess Deep sampled by submersible are depleted in ${ }^{18} \mathrm{O}\left(\delta^{18} \mathrm{O}=4.8 \pm\right.$ $0.9 \%, \mathrm{n}=12$ ), however, suggesting that the upper gabbro section as a whole is depleted in ${ }^{18} \mathrm{O}$ [Agrinier et al., 1995; Gillis et al., 2001]. Six whole rocks sampled by submersible from the deeper $\sim 1.5 \mathrm{~km}$ plutonic section have generally low $\delta^{18} \mathrm{O}$ values of $4.2-6.7 \%$, with a mean of 5.6\% ( \pm 0.8 [Agrinier et al., 1995]). In contrast, rhodingitized and mylonitized gabbros from the deeper section and altered at somewhat lower temperatures tend to be enriched in ${ }^{18} \mathrm{O}\left(\delta^{18} \mathrm{O}=\right.$ 4.7-8.0\%, $\mathrm{n}=3$ [Agrinier et al., 1995]). Thus the Hess Deep plutonic section appears to be slightly depleted in ${ }^{18} \mathrm{O}$ overall, but this depends critically on the abundance of retrograde effects, which are unquantified. Retrograde effects at Hess Deep, however, are associated with fractures related to rifting of the basement associated with the propagating Galapagos Rift [Fruh-Green et al., 1996]. These retrograde effects thus may not be present or would at least be less abundant in more typical, unrifted crust formed at fast spreading rates, suggesting that these plutonic sections most likely exhibit overall ${ }^{18} \mathrm{O}$ depletions.

[51] The limited numbers of samples over large depth intervals and the heterogeneity of alteration effects in these sections make quantification difficult. These oceanic plutonic sections, however, all exhibit net ${ }^{18} \mathrm{O}$ depletions, in contrast to the possible slight overall ${ }^{18} \mathrm{O}$ enrichment or no change exhibited by the Hole 735B plutonic section. Given the available data there is no clear difference in oxygen isotope effects between plutonic oceanic crust formed at fast and slow spreading rates. Moreover, three of the four sections described above share the feature of having maximum alteration effects and ${ }^{18} \mathrm{O}$-depletions in the uppermost few hundred meters of the plutonic sections.

\subsubsection{Ophiolites}

[52] Oxygen isotope profiles through ophiolites have recently been summarized by Muehlenbachs [1998], Alt and Teagle [2001], and Gao et al. [2006]. The plutonic sections in most ophiolites are depleted in ${ }^{18} \mathrm{O}$, although the degree of depletion and the depth to which ${ }^{18} \mathrm{O}$ depletions extend vary from site to site. These sections include the Semial Ophiolite in Oman and the Troodos Ophiolite in Cyprus, which formed at fast and slow spreading rates, respectively [Bickle and Teagle, 1992; Gregory and Taylor, 1981]. 
[53] In contrast, the plutonic sections of some ophiolites are enriched in ${ }^{18} \mathrm{O}$ as the result of lower-temperature reactions that are superimposed on early high-temperature effects [Agrinier et al., 1988; Harper et al., 1988; Barrett and Friedrichsen, 1989; Schiffman et al., 1991; Lecuyer and Fourcade, 1991]. In some cases these ${ }^{18} \mathrm{O}$-enrichments can be attributed to the specific tectonic setting. Schiffman et al. [1991] discuss the Coast Range ophiolite in terms of a rifted arc, where burial by sediments and a long duration of magmatic activity resulted in prolonged hydrothermal circulation in gabbros at lower temperatures $\left(<250^{\circ} \mathrm{C}\right)$, and possible ${ }^{18} \mathrm{O}$-enrichment of fluids via reaction with pelagic sediments.

[54] The ${ }^{18} \mathrm{O}$ enrichment of plutonic sections of the Trinity, Xigaze and Ligurian ophiolites has been attributed to formation of these ophiolites at slowspreading ridges, where tectonic disruption and uplift allowed prolonged penetration of fluids and alteration of the lower crust at temperatures less than $\sim 250^{\circ} \mathrm{C}$ superimposed on early high-temperature alteration [Agrinier et al., 1988; Barrett and Friedrichsen, 1989; Lecuyer and Fourcade, 1991]. Thus tectonic setting may be a factor, with slow spreading rates allowing exposure of the lower crust to greater amounts of lower-temperature alteration and ${ }^{18} \mathrm{O}$ enrichment, but slow spreading rates do not always result in ${ }^{18} \mathrm{O}$ enrichment of plutonic crust. The Troodos ophiolite and ocean crust of the Cayman Trough and Macquarie Island formed at slow spreading rates, but these plutonic sections exhibit net ${ }^{18} \mathrm{O}$ depletions.

\section{Summary and Conclusions}

[55] Whole rock $\delta^{18} \mathrm{O}$ values from the deeper $1 \mathrm{~km}$ of the $1.5 \mathrm{~km}$ lower crustal section of ODP Hole $735 \mathrm{~B}$ exhibit ${ }^{18} \mathrm{O}$-depletions and enrichments relative to fresh rock, ranging from 3.7 to $10.2 \%$, with most values in the range $5.6-7.6 \%$. The ${ }^{18} \mathrm{O}$ depletions and enrichments reflect alteration of the section by multiple hydrothermal processes.

[56] Stable isotope compositions of amphiboles provide evidence for early fluids containing a magmatic component. Amphiboles having $\delta \mathrm{D}=$ -35 to $-49 \%$ are consistent with formation from seawater fluids at temperatures of $400-500^{\circ} \mathrm{C}$, but amphiboles having lower $\delta \mathrm{D}$ values $(-50$ to $-65 \%$ ) formed from modified seawater fluids containing a component of magmatic fluids $(\delta \mathrm{D}$ $=-65$ to $-80 \%$ ). Magmatic fluids may be a common component in early alteration of oceanic plutonic sections.

[57] Crystal-plastic shear zones formed at granulite to amphibolite grade conditions (up to $800-$ $1000^{\circ} \mathrm{C}$ ). These rocks have $\delta^{18} \mathrm{O}$ values of 6.0 $7.0 \%$, indistinguishable from the surrounding rocks, reflecting reaction with ${ }^{18} \mathrm{O}$-enriched fluids $\left(\delta^{18} \mathrm{O}=1 \%\right.$ to $>5 \%$ o $)$ at high temperatures $\left(>400^{\circ} \mathrm{C}\right)$.

[58] Local ${ }^{18} \mathrm{O}$-depleted rocks containing amphibole and secondary plagioclase ( \pm secondary clinopyroxene) reflect alteration by seawaterdominated fluids at high temperatures $(\sim 500$ $\left.700^{\circ} \mathrm{C}\right)$.

[59] Much of the Leg 176 section is slightly altered, containing only $1-2 \%$ secondary minerals, yet the rocks have $\delta^{18} \mathrm{O}$ values of up to $7.6 \%$. This is interpreted as the result of cryptic alteration of plagioclase over a range of temperatures and fluid compositions (from ${ }^{18} \mathrm{O}$-enriched hydrothermal fluids at up to $\sim 600^{\circ} \mathrm{C}$, to seawater at temperatures down to $<250^{\circ} \mathrm{C}$ ).

[60] Syntectonic differentiation of gabbros led to migration of late iron-rich melts into shear zones, where high-temperature crystal-plastic and later brittle-ductile deformation took place. The wide range of $\delta^{18} \mathrm{O}$ values of oxide gabbros (3.9-7.2\%) reflect fluid flow through these zones as the crustal section cooled and fluid compositions evolved. Felsic veins formed locally from late magmatic hydrous melts and fluids, but are overprinted by retrograde hydrothermal alteration throughout the history of the crustal section, which is reflected in the range of $\delta^{18} \mathrm{O}$ values for these veins (4.6-6.9\%).

[61] Retrograde alteration led to formation of greenschist assemblages and bulk rock ${ }^{18} \mathrm{O}$-depletions locally (especially at 1475-1506 mbsf). More common are the effects of lower-temperature alteration producing smectite-chlorite, smectite, quartz, albite, zeolites, and calcite, and resulting in local ${ }^{18} \mathrm{O}$-enrichments of the rocks (up to $10.2 \%$ ). These effects are associated with brittle fractures and active faults related to uplift and cooling of the crustal block. Chlorite-rich veins formed from evolved, ${ }^{18} \mathrm{O}$-enriched seawater-derived fluids, and late carbonates associated with active faults at $500-600 \mathrm{mbsf}$ formed from cold $\left(\sim 10^{\circ} \mathrm{C}\right)$ seawater.

[62] On average, the Leg 176 section (500-1506 $\mathrm{mbsf}$ ) is enriched in ${ }^{18} \mathrm{O}$ compared to fresh gabbro $\left(\delta^{18} \mathrm{O}=6.5 \pm 1.0 \%\right.$ versus $\sim 5.8 \%$ ) . This results 
from reaction with ${ }^{18} \mathrm{O}$-enriched fluids at high temperatures $\left(>350^{\circ} \mathrm{C}\right)$ and from lower-temperature alteration $\left(<250^{\circ} \mathrm{C}\right)$. The contribution of reaction with ${ }^{18} \mathrm{O}$-enriched fluids to high $\delta^{18} \mathrm{O}$ values of the rocks may be somewhat greater than that from low-temperature alteration. The ${ }^{18} \mathrm{O}$-enrichments of the fluids may be produced by reaction of seawater with shallower basement at high temperatures, as fluids penetrate downward into the lower crust. The ${ }^{18} \mathrm{O}$ enrichment of the deeper $1 \mathrm{~km}$ contrasts with the upper $500 \mathrm{~m}$ of the section, which exhibits a net ${ }^{18} \mathrm{O}$ depletion $(5.1 \pm 1.0 \%)$ reflecting hydrothermal alteration by seawaterdominated fluids. The weighted average $\delta^{18} \mathrm{O}$ for the entire gabbro section of Hole $735 \mathrm{~B}$ is $6.0 \%$, possibly slightly enriched in ${ }^{18} \mathrm{O}$ compared to unaltered crust, but little changed. Although slow spreading rates may allow exposure of lower crust to greater amounts of low-temperature alteration and ${ }^{18} \mathrm{O}$ enrichment, there is no evidence for a consistent difference in the bulk $\delta^{18} \mathrm{O}$ of the plutonic sections of oceanic crust formed at fast versus slow spreading rates.

\section{Acknowledgments}

[63] This work was supported by NSF OCE-0220964. J.C.A. thanks Lora Wingate for assistance with analyses, K. C. Lohmann for use of laboratory facilities, and Jan Hertogen for supplying shipboard rock powders. The authors thank Gretchen Fruh-Green for a helpful review. This research used samples and/or data provided by the Ocean Drilling Program. The ODP is sponsored by the U.S. National Science Foundation (NSF) and participating countries under the management of Joint Oceanographic Institutions (JOI).

\section{References}

Agrinier, P., M. Javoy, and J. Girardeau (1988), Hydrothermal activity in a peculiar oceanic ridge: Oxygen and hydrogen isotope evidence in the Xigaze ophiolite (Tibet, China), Chem. Geol., 71, 313-335.

Agrinier, P., R. Hekinian, D. Bideau, and M. Javoy (1995), $\mathrm{O}$ and $\mathrm{H}$ stable isotope compositions of oceanic crust and upper mantle rocks exposed in the Hess Deep near the Galapagos Triple Junction, Earth Planet. Sci. Lett., 136, 183-196.

Alt, J. C. (1995), Subseafloor processes in mid-ocean ridge hydrothermal systems, in Seafloor Hydrothermal Systems: Physical, Chemical, and Biological Interactions, Geophys. Monogr. Ser., vol. 91, edited by S. Humphris et al., pp. 85114, AGU, Washington, D. C.

Alt, J. C. (2003), Stable isotopic composition of upper oceanic crust formed at a fast spreading ridge, ODP Site 801, Geochem. Geophys. Geosyst., 4(5), 8908, doi:10.1029/ 2002GC000400.

Alt, J. C. (2004), Alteration of the upper oceanic crust: Mineralogy, chemistry, and processes, in Hydrogeology of the Oceanic Lithosphere, edited by H. Elderfield and E. Davis, pp. 456-488, Cambridge Univ. Press, New York.
Alt, J. C., and W. Bach (2001), Low grade hydrothermal alteration of uplifted lower oceanic crust, Hole 735B: Mineralogy and isotope geochemistry [online], Proc. Ocean Drill. Program Sci. Results, 176. (http://www-odp.tamu. edu/publications/176_SR/chap_01/chap_01.htm)

Alt, J. C., and D. A. H. Teagle (2001), Hydrothermal alteration and fluid fluxes in ophiolites and oceanic crust, in Ophiolites and Oceanic Crust: New Insights From Field Studies and Ocean Drilling Program, edited by Y. Dilek et al., Spec. Pap. Geol. Soc. Am., 349, 273-282.

Bach, W., J. C. Alt, Y. Niu, S. E. Humphris, J. Erzinger, and H. J. B. Dick (2001a), The chemical consequences of late-stage hydrothermal circulation in an uplifted block of lower ocean crust at the SW Indian Ridge: Results from ODP Hole 735B (Leg 176), Geochim. Cosmochim. Acta, 19, 3267-3287.

Bach, W., J. C. Alt, and S. E. Humphris (2001b), A geochemical and isotopic study of the magmatic-hydrothermal transition in the lower oceanic crust (ODP Hole 735B) (abstract), paper presented at GSA Annual Meeting, Geol. Soc. of Am., Boston, Mass.

Barrett, T. J., and H. Friedrichsen (1989), Stable isotopic compositions of atypical ophiolitic rocks from east Liguria, Italy, Chem. Geol., 80, 71-84.

Bickle, M. J., and D. A. H. Teagle (1992), Strontium alteration in the Troodos ophiolite: Implications for fluid fluxes and geochemical transport in mid-ocean ridge hydrothermal systemsEarth Planet. Sci. Lett., 113, 219-237.

Bottinga, Y., and M. Javoy (1975), Oxygen isotope partitioning among the minerals and triplets in igneous and metamorphic rocks, Rev. Geophys., 13, 401-418.

Cannat, M., C. Mevel, and D. Stakes (1991), Normal ductile shear zones at an oceanic spreading ridge: Tectonic evolution of Site 735 gabbros (southwest Indian Ocean), Proc. Ocean Drill. Program Sci. Results, 118, 415-429.

Carbotte, S. M., and D. S. Scheirer (2004), Variability of ocean crustal structure created along the global mid-ocean ridge, in Hydrogeology of the Oceanic Lithosphere, edited by H. Elderfield and E. Davis, pp. 59-107, Cambridge Univ. Press, New York.

Clayton, R. N., and T. K. Mayeda (1963), The use of bromine pentafluoride in the extraction of oxygen from oxides and silicates for isotopic analysis, Geochim. Cosmochim. Acta, $27,43-52$.

Cocker, J. D., B. J. Griffin, and K. Muehlenbachs (1982), Oxygen and carbon isotope evidence for seawater-hydrothermal alteration of the Macquarie Island ophiolite, Earth Planet. Sci. Lett., 61, 112-122.

Dick, H. J. B., P. S. Meyer, S. Bloomer, S. Kirby, D. Stakes, and C. Mawer (1991), Lithostratigraphic evolution of an insitu section of oceanic Layer 3, Proc. Ocean Drill. Program Sci. Results, 118, 439-538.

Dick, H. J. B., et al. (2000), A long in-situ section of the lower ocean crust: Results of ODP Leg 176 drilling at the southwest Indian Ridge, Earth Planet. Sci. Lett., 179, 31-51.

Eiler, J. M., A. J. Crawford, T. R. Elliot, K. A. Farley, J. W. Valley, and E. M. Stolper (2000), Oxygen isotope geochemistry of oceanic arc lavas, J. Petrol., 21(2), 229-256.

Elthon, D., J. R. Lawrence, R. E. Hanson, and C. Stern (1984), Modeling of oxygen isotope data from the Sarmiento ophiolite complex, Chile, in Ophiolites and Oceanic Lithosphere, edited by I. G. Gass, S. J. Lippard, and A. W. Shelton, Geol. Soc. Spec. Publ., 13, 185-197.

Expedition 309 and 312 Scientists (2006), Superfast spreading rate crust 3: A complete in situ section of upper oceanic crust formed at a superfast spreading rate, IODP Prelim. Rep., 
312, doi:10:2204/iodp.pr.312, Integrated Ocean Drill. Program, College Station, Tex.

Fruh-Green, G. L., A. Plas, and L. N. Dell'Angelo (1996), Mineralogical and stable isotope record of polyphase alteration of upper crustal gabbros of the East Pacific Rise (Hess Deep, Site 894), Proc. Ocean Drill. Program Sci. Results, 147, 235-254.

Gao, Y., J. Hoefs, R. Przybilla, and J. E. Snow (2006), A complete oxygen isotope profile through the lower oceanic crust, ODP Hole 735B, Chem. Geol., 233, 217-234.

Gillis, K. M. (1995), Controls on hydrothermal alteration in a section of fast spreading oceanic crust, Earth Planet. Sci. Lett., 134, 473-489.

Gillis, K. M., K. Muehlenbachs, M. Stewart, T. Gleeson, and J. Karson (2001), Fluid flow patterns in fast spreading East Pacific Rise crust exposed at Hess Deep, J. Geophys. Res., 106(B11), 26,311-26,329.

Gregory, R. T. (1991), Oxygen isotope history of seawater revisited: Timescales for boundary event changes in the oxygen isotope composition of seawater, in Stable Isotope Geochemistry: A Tribute to Samuel Epstein, edited by H. Taylor, J. R. O'Neil, and I. Kaplan, Spec. Publ. Geochem. Soc., 3, $65-76$.

Gregory, R. T., and H. P. Taylor (1981), An oxygen isotope profile in a section of Cretaceous oceanic crust, Samail ophiolite, Oman: Evidence for $\delta^{18} \mathrm{O}$ buffering of the oceans by deep $(>5 \mathrm{~km})$ seawater-hydrothermal circulation at midocean ridges, J. Geophys. Res., 86, 2737-2755.

Harmon, R. S., and J. Hoefs (1995), Oxygen isotope heterogeneity of the mantle deduced from global ${ }^{18} \mathrm{O}$ systematics of basalts from different geotectonic settings, Contrib. Mineral. Petrol., 120(1), 95-114.

Harper, G. D., J. R. Bowman, and R. Kuhns (1988), A field, chemical, and stable isotope study of subseafloor metamorphism of the Josephine ophiolite, California-Oregon, J. Geophys. Res., 93, 4625-4656.

Hertogen, J., R. Emmermann, P. T. Robinson, and J. Erzinger (2002), Lithology, mineralogy, and geochemistry of the lower ocean crust, ODP Hole 735B, Southwest Indian Ridge [online], Proc. Ocean Drill. Program Sci. Results, 176, 82 pp. (Available at http://www-odp.tamu.edu/publications/ 176_SR/VOLUME/CHAPTERS/SR176_06. PDF)

Ito, E., and R. N. Clayton (1983), Submarine metamorphism of gabbros from the Mid-Cayman rise: An oxygen isotopic study, Geochim. Cosmochim. Acta, 47, 535-546.

Kelley, D. S. (1996), Methane-rich fluids in the oceanic crust, J. Geophys. Res., 101, 2943-2962.

Kelley, D. S., and G. Fruh-Green (1999), Abiogenic methane in deep-seated mid-ocean ridge environments: Insights from stable isotope analyses, J. Geophys. Res., 104, 10,43910,460 .

Kelley, D. S., and G. Fruh-Green (2001), Volatiles in midocean ridge environments, in Ophiolites and Oceanic Crust: New Insights From Field Studies and the Ocean Drilling Program, edited by Y. Dilek et al., Spec. Pap. Geol. Soc. Am., 349, 237-260.

Kempton, P. D., C. J. Hawkesworth, and M. Fowler (1991), Geochemistry and isotopic composition of gabbros from Layer 3 of the Indian Ocean crust, Hole 735B, Proc. Ocean Drill. Program Sci. Results, 118, 127-143.

Lecuyer, C., and S. Fourcade (1991), Oxygen isotope evidence for multi-stage hydrothermal alteration at a fossil slowspreading center: The Silurian Trinity ophiolite (California, USA), Chem. Geol., 87, 231-246.

Lecuyer, C., and G. Gruau (1996), Oxygen and strontium isotope compositions of Hess Deep Gabbros (Holes 894F and
894G): High-temperature interaction of seawater with the oceanic crust layer 3, Proc. Ocean Drill. Program Sci. Results, 147, 227-234.

Manning, C. E., C. J. MacLeod, and P. E. Weston (2000), Lower crustal cracking front at fast-spreading ridges: Evidence from the East Pacific Rise and the Oman ophiolite, in Ophiolites and Oceanic Crust: New Insights From Field Studies and the Ocean Drilling Program, edited by Y. Dilek et al., Spec. Pap. Geol. Soc. Am., 349, 261-272.

Matthews, A., J. R. Goldsmith, and R. N. Clayton (1983), Oxygen isotope fractionations involving pyroxenes: The calibration of mineral-pair geothermometers, Geochim. Cosmochim. Acta, 47, 631-644.

Mevel, C., and M. Cannat (1991), Lithospheric stretching and hydrothermal processes in oceanic gabbros from slow spreading ridges, in Ophiolite Genesis and Evolution of the Oceanic Lithosphere, edited by T. Peters, A. Nicolas and R. G. Coleman, pp. 293-312, Elsevier, New York.

Muehlenbachs, K. (1980), The alteration and aging of the basaltic layer of the seafloor: Oxygen isotope evidence from DSDP/IPOD Legs 51, 52, and 53, Init. Rep. Deep Sea Drill Proj., 51-53, 1159-1167.

Muehlenbachs, K. (1998), The oxygen isotopic composition of the oceans, sediments and the seafloor, Chem. Geol., 145, $263-273$.

Muehlenbachs, K., and R. N. Clayton (1972), Oxygen isotope studies of fresh and weathered submarine basalts, Can. J. Earth Sci., 9, 172-184

Muehlenbachs, K., and R. N. Clayton (1976), Oxygen isotope composition of the oceanic crust and its bearing on seawater, J. Geophys. Res., 81, 4365-4369.

Natland, J. H., and H. J. B. Dick (1996), Melt migration through high-level gabbroic cumulates of the East Pacific Rise at Hess Deep: The origin of magma lenses and the deep crustal structure of fast-spreading ridges, Proc. Ocean Drill. Program Sci. Results, 147, 21-58.

O'Neil, J. R., and H. P. Taylor (1967), The oxygen isotope and cation exchange chemistry of feldspars, J. Geophys. Res., 74, 6012-6022.

Schiffman, P., R. C. Evarts, A. E. Williams, and W. P. Pickthorn (1991), Hydrothermal metamorphism in oceanic crust from the Coast Range ophiolite of California: Fluidrock interaction in a rifted arc, in Ophiolite Genesis and Evolution of the Oceanic Lithosphere, edited by T. Peters, A. Nicolas, and R. G. Coleman, pp. 399-426, Elsevier, New York.

Sharp, Z. D., and D. L. Kirschner (1994), Quartz-calcite oxygen isotope geothermometry: A calibration based on natural isotopic variations, Geochim. Cosmochim. Acta, 58, 44914502.

Shipboard Scientific Party (1999), Leg 176, Proc. Ocean Drill. Program Initial Rep., 176, 1-70. (Available at http://wwwodp.tamu.edu/publications/176_IR/176ir.htm)

Stakes, D. (1991), Oxygen and hydrogen isotope compositions of oceanic plutonic rocks: High-temperature deformation and metamorphism of oceanic layer 3, in Stable Isotope Geochemistry: A Tribute to Samuel Epstein, edited by H. Taylor, J. R. O'Neil and I. Kaplan, Spec. Publ. Geochem. Soc., 3, 77-90.

Stakes, D. S., and H. P. Taylor (1992), The northern Samail ophilite: An oxygen isotope, microprobe, and field study, J. Geophys. Res., 97, 7043-7080.

Stakes, D., C. Mével, M. Cannat, and T. Chaput (1991), Metamorphic stratigraphy of Hole 735B, Proc. Ocean Drill. Program Sci. Results, 118, 153-181. 
Suzuoki, T., and S. Epstein (1976), Hydrogen isotope fractionation between $\mathrm{OH}$-bearing minerals and water, Geochim. Cosmochim. Acta, 40, 1229-1240.

Taylor, H. P. (1977), Water/rock interactions and the origin of $\mathrm{H}_{2} \mathrm{O}$ in granitic batholiths, J. Geol. Soc. London, 133, 509558.

Taylor, H. P., and S. M. F. Sheppard (1986), Igneous Rocks: I, in Stable Isotopes in High-Temperature Geological Processes, Rev. Mineral., vol. 16, edited by J. W. Valley, H. P. Taylor, and J. R. O'Neil, pp. 277-271, Mineral. Soc. of Am., Washington, D. C.

Vanko, D. A., and D. S. Stakes (1991), Fluids in oceanic Layer 3: Evidence from veined rocks, Hole 735B, Southwest Indian Ridge, Proc. Ocean Drill. Program Sci. Results, 118, $181-218$.

Varne, R., A. V. Brown, and T. Falloon (2000), Macquarie Island: Its geology, structural history, and the timing and tectonic setting of its N-MORB to E-MORB magmatism, in Ophiolites and Oceanic Crust: New Insights From Field Studies and the Ocean Drilling Program, edited by Y. Dilek et al., Spec. Pap. Geol. Soc. Am., 349, 301-320.

Venneman, T. W., and J. R. O'Neil (1993), A simple and inexpensive method of hydrogen isotope and water analyses of minerals and rocks based on zinc reagent, Chem. Geol., $103,227-334$.

Von Herzen, R. P., et al. (1989), Proceedings of the Ocean Drilling Program, Science Results, vol. 118, 597 pp., Ocean Drill. Program, College Station, Tex.

Wenner, D. B., and H. P. Taylor (1971), Temperatures of serpentinization of ultramafic rocks based on ${ }^{18} \mathrm{O} /{ }^{16} \mathrm{O}$ fractionation between coexisting serpentine and magnetite, Contrib. Mineral. Petrol., 32, 165-185.

Wilson, D., et al. (2006), Drilling to gabbro in intact ocean crust, Science, 312, 1016-1020. 